\title{
Horizontal nutrient fluxes and food safety in urban and peri-urban vegetable and millet cultivation of Niamey, Niger
}

\author{
Rodrigue V. C. Diogo • Andreas Buerkert • \\ Eva Schlecht
}

Received: 12 February 2009/Accepted: 24 August 2009/Published online: 17 September 2009

(C) The Author(s) 2009. This article is published with open access at Springerlink.com

\begin{abstract}
Urban and peri-urban agriculture (UPA) has often been accused of being nutrient inefficient and producing negative externalities. To investigate these problems for the West African capital Niamey (Niger), nutrient inputs through fertilizer and manure to 10 vegetable gardens and 9 millet fields and nutrient offtakes through harvests were quantified during 24 months, and contamination of irrigation water and selected vegetables with faecal pathogens and heavy metals was determined. Annual partial horizontal balances for carbon (C), nitrogen (N), phosphorus $(\mathrm{P})$ and potassium $(\mathrm{K})$ amounted to $9,936 \mathrm{~kg} \mathrm{C} \mathrm{ha}{ }^{-1}, 1,133 \mathrm{~kg} \mathrm{~N}^{-1}, 223 \mathrm{~kg} \mathrm{P} \mathrm{ha}^{-1}$ and $312 \mathrm{~kg} \mathrm{~K} \mathrm{ha}^{-1}$ in high input vegetable gardens as opposed to $9,580 \mathrm{~kg} \mathrm{C}^{-1}, 290 \mathrm{~kg} \mathrm{~N}^{-1}, 125 \mathrm{~kg}$ $\mathrm{P} \mathrm{ha}^{-1}$ and $351 \mathrm{~kg} \mathrm{~K} \mathrm{ha}^{-1}$ in low input gardens. In high input millet fields, annual surpluses of $259 \mathrm{~kg} \mathrm{C}$ $\mathrm{ha}^{-1}, 126 \mathrm{~kg} \mathrm{~N}^{-1}, 20 \mathrm{~kg} \mathrm{P} \mathrm{ha}^{-1}$ and $0.4 \mathrm{~kg} \mathrm{~K}$ $\mathrm{ha}^{-1}$ were recorded, whereas surpluses of $12 \mathrm{~kg} \mathrm{C}$ $\mathrm{ha}^{-1}, 17 \mathrm{~kg} \mathrm{~N} \mathrm{ha}^{-1}$, and deficits of $-3 \mathrm{~kg} \mathrm{P} \mathrm{ha}^{-1}$
\end{abstract}

\section{R. V. C. Diogo · E. Schlecht $(\bowtie)$}

Animal Husbandry in the Tropics and Subtropics,

University of Kassel and Georg-August-Universität

Göttingen, Steinstrasse 19, 37213 Witzenhausen,

Germany

e-mail: tropanimals@uni-kassel.de

\section{A. Buerkert}

Organic Plant Production and Agroecosystems Research in the Tropics and Subtropics, University of Kassel, Steinstrasse 19, 37213 Witzenhausen, Germany and $-3 \mathrm{~kg} \mathrm{~K} \mathrm{ha}{ }^{-1}$ were determined for low input fields. Counts of Salmonella spp. and Escherichia coli yielded above threshold contamination levels of $7.2 \times 10^{4} \mathrm{CFU} 25 \mathrm{~g}^{-1}$ and $3.9 \times 10^{4} \mathrm{CFU} \mathrm{g}^{-1}$ in lettuce irrigated with river water and fertilized with animal manure. Salmonella counts averaged $9.8 \times$ $10^{4} \mathrm{CFU} 25 \mathrm{~g}^{-1}$ and E. coli $0.6 \times 10^{4} \mathrm{CFU} \mathrm{g}^{-1}$ for lettuce irrigated with wastewater, while these pathogens were not detected on vegetables irrigated with pond water. These results underline the need for urban gardeners to better adjust the nutrients applied to crop requirements which might also reduce nutrient accumulations in the soil and further in the edibles parts of the vegetables. Appropriate pretreatment of irrigation water would help improve the quality of the latter and enhance the food safety of vegetables determined for the urban markets.

Keywords Microbial contamination .

Nutrient balance · Urban agriculture .

West Africa

\section{Introduction}

During the last decade the use of open inner-city and peripheral spaces for urban and peri-urban agriculture (UPA) has become increasingly important in Africa to enhance the food supply to the population of the 
rapidly growing cities (Bryld 2003; Cofie et al. 2003). Intensively managed UPA systems can provide farmers with additional opportunities for employment, income and subsistence food (Rabinovitch and Schmetzer 1997; Lynch et al. 2001; Drechsel et al. 2006; Nguni and Mwila 2007; Thornton 2008). Moreover, UPA can contribute positively to poverty alleviation and social integration of disadvantaged and marginalized groups such as handicapped, sick or old people, female-headed families, children and jobless uneducated young people (van Veenhuizen and Danso 2007). Furthermore, these production systems allow consumers to purchase fresh vegetables and fruits as well as eggs, fresh meat and milk, poultry and fish (Cofie et al. 2001; Niang et al. 2002; Drechsel et al. 2007) on urban and local markets. To achieve these multiple objectives UPA makes use of typical urban resources such as, organic municipal waste, sewage and market refuse in crop production, which have often been found to cause microbial and heavy metal contamination of produce (Keraita and Drechsel 2002; Amoah et al. 2005; Akegbejo-Samsons 2008). Besides solid organic and liquid wastes, household wastes, contaminated livestock and poultry manures were reported to be sources of pathogen contaminations mainly of faecal origin (Guendel 2002; Sonou 2001; Drechsel et al. 2006). While manure application on UPA soils may reach up to $100 \mathrm{t} \mathrm{ha}^{-1}$ year $^{-1}$, mineral fertilizers are often used as an additional nutrient source for vegetables such as cabbage (Brassica oleracea L.; Drechsel et al. 2005). In Lomé (Togo), for example, farmers used a combination of cotton (Gossypium hirsutum) grain, different manures and mineral fertilizers as soil amendments (Schreurs 2001). From the South of Benin high inputs of organic $\left(>40 \mathrm{t} \mathrm{ha}^{-1}\right)$ and mineral fertilisers $\left(>600 \mathrm{~kg} \mathrm{ha}^{-1}\right)$ were reported as inputs for African eggplant (Solanum aethiopicum L.; Assogba-Komlan et al. 2007). In the Sahelian cities of Bamako (Mali), Ouagadougou (Burkina Faso) and Niamey (Niger), where large-scale poultry farming is constrained by heat, the combined application of cattle manure and mineral fertilizers in UPA systems is common (Drechsel et al. 2006; Graefe et al. 2008). In Niamey, the intensive fertilizer application to UPA gardens (Graefe et al. 2008) suggests strongly positive horizontal nutrient balances that may result in large gaseous and leaching losses of nutrients and environmental pollution. This is obviously in strong contrast to the negative nutrient balances reported for rural West African farming systems (Stoorvogel and Smaling 1990; Van den Bosch et al. 1998). However, detailed studies are lacking that quantify the nutrient flows and balances in the UPA systems of this region.

As such nutrient balances are of interest both from an economic and environmental point of view and have been used to evaluate the sustainability of farming systems at different scales (Nielsen and Kristensen 2005; He et al. 2007; Kyllingsbæk and Hansen 2007; Khai et al. 2007; Guo et al. 2008). The difference between the sum of nutrient inputs and the sum of nutrient outputs indicates a surplus or deficit for the system and depending on the objectives and scales of the research, different types of nutrient balances can be used. In this study we used the soil surface nutrient budget approach (Oenema et al. 2003; Bassanino et al. 2007) to quantify management-related horizontal nutrient fluxes and balances in UPA vegetable and millet farming systems of the Sahelian city of Niamey. More specifically, our objectives were (i) to quantify the managementbased horizontal fluxes and balances of carbon (C), nitrogen $(\mathrm{N})$, phosphorus $(\mathrm{P})$ and potassium $(\mathrm{K})$ at the level of gardens and fields, and (ii) to determine the concentrations of heavy metals and faecal pathogens in irrigation water used and the thus irrigated leafy vegetables.

\section{Materials and methods}

Study area and cropping systems

The study was carried out in Niamey $\left(13.5^{\circ} \mathrm{N}, 2.2^{\circ} \mathrm{E}\right.$; $220 \mathrm{~m}$ asl), the capital city of the Republic of Niger, which currently has around 900,000 inhabitants who are estimated to increase to 2.5 Mio in 2025 (Maurice 2003). The region's climate is semi-arid with a single rainy season from June to October and an 80-year average precipitation of $577 \mathrm{~mm}_{\text {year }}{ }^{-1}$ (L'Hôte et al. 2002). During the study period (January 2006-January 2008), annual rainfall recorded was substantially lower than this average and, equally typical for semiarid climates, varied substantially between different experimental sites within the city (Table 1). During the cool dry season (November-February), average daily temperatures range from 16 to $32^{\circ} \mathrm{C}$ and are 


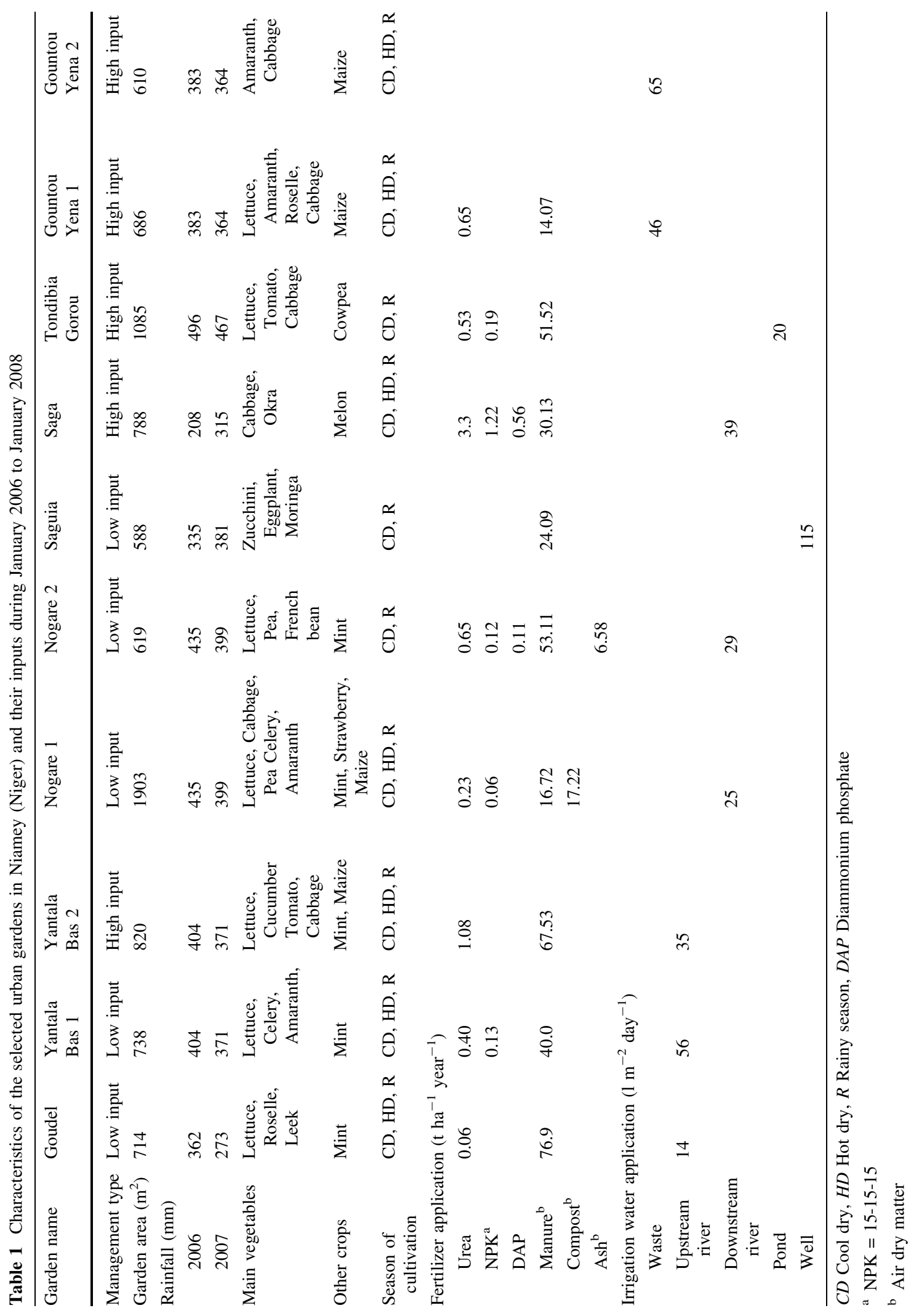


lowest in January $\left(24^{\circ} \mathrm{C}\right)$; during the hot dry season (March-May) average daily temperatures range from 27 to $41^{\circ} \mathrm{C}$ and peak in April/May $\left(34^{\circ} \mathrm{C}\right)$.

The city area under study covers $672 \mathrm{~km}^{2}$ with the major built-up part located north of the Niger River that separates Niamey at a length of about $15 \mathrm{~km}$. This northern part is crossed from north to south by a major riverbed (wadi) through which water drains nearly year-round into the Niger River. Most of the UPA activities, especially gardening, are located along this wadi and the Niger River. Niamey's UPA is mainly characterized by intensive urban and periurban vegetable gardening and some peri-urban millet farming associated with intensive sheep and goat husbandry in the city centre and extensive cattle keeping at the outskirts of the city (Graefe et al. 2008). The input-intensive, largely market-oriented vegetable gardening is dominated by exotic crop species (Table 1), whereby in contrast to popular judgement species richness was found to increase with market orientation and partly with garden size (Bernholt et al. 2009). At the city's outskirts millet (Pennisetum glaucum L.) and sorghum (Sorghum bicolor L.) intercropped mainly with cowpea (Vigna unguiculata L.) and occasionally groundnut (Arachis hypogea $\mathrm{L}$.) are cultivated as staple food.

For this study 10 vegetable gardens (Table 1) and 9 millet fields (Table 2) representing the diversity of UPA crop production systems were selected on the basis of a preceding study (Graefe et al. 2008) and were closely monitored, to quantify the management-related nutrient inputs (INs) and outputs (OUTs) (Fig. 1). Based on the management intensity, and especially the nutrient input to individual gardens and fields, respectively, these were categorized as high or low input systems. While in gardens high input systems were also strongly market-oriented, low input systems were mainly managed for home consumption. This differentiation could not be made for the millet fields which all served home-consumption.

Three and five sampling plots were installed in each garden and field, respectively. Their size varied from 1 to $10 \mathrm{~m}^{2}$ for small gardens and from 10 to $25 \mathrm{~m}^{2}$ for large ones, while in the fields, observed plot sizes were $100 \mathrm{~m}^{2}$. The total area of fields and gardens as well as the individual plot sizes were determined using a hand-held differential Global Positioning System (GPS; Trimble Pro XR, Sunnyvale, CA, USA). This data was imported into a

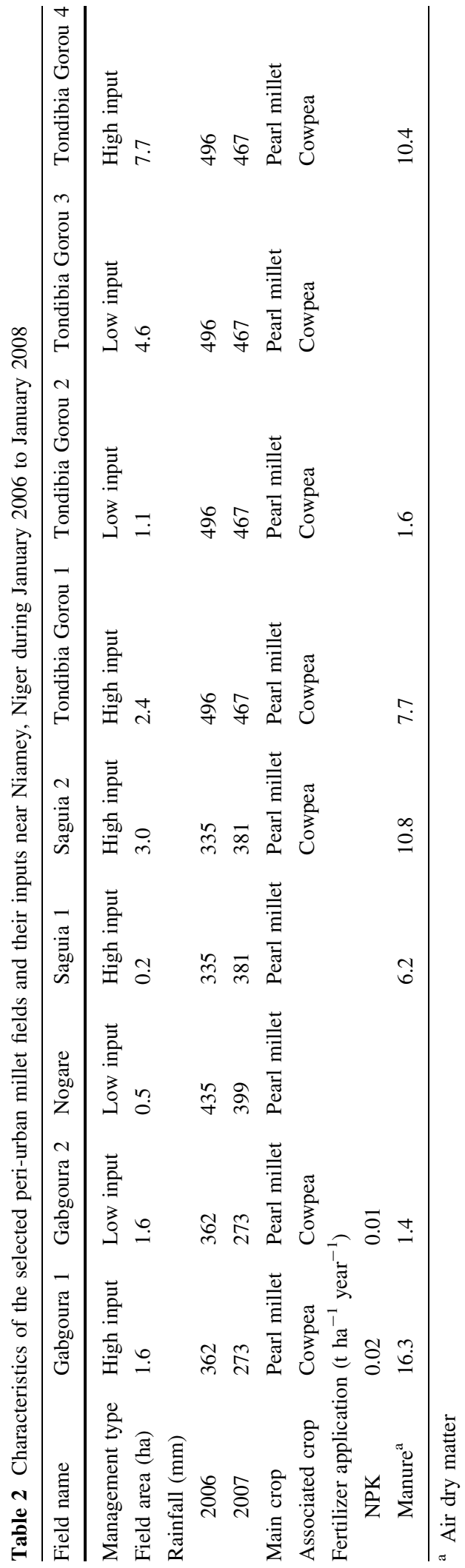




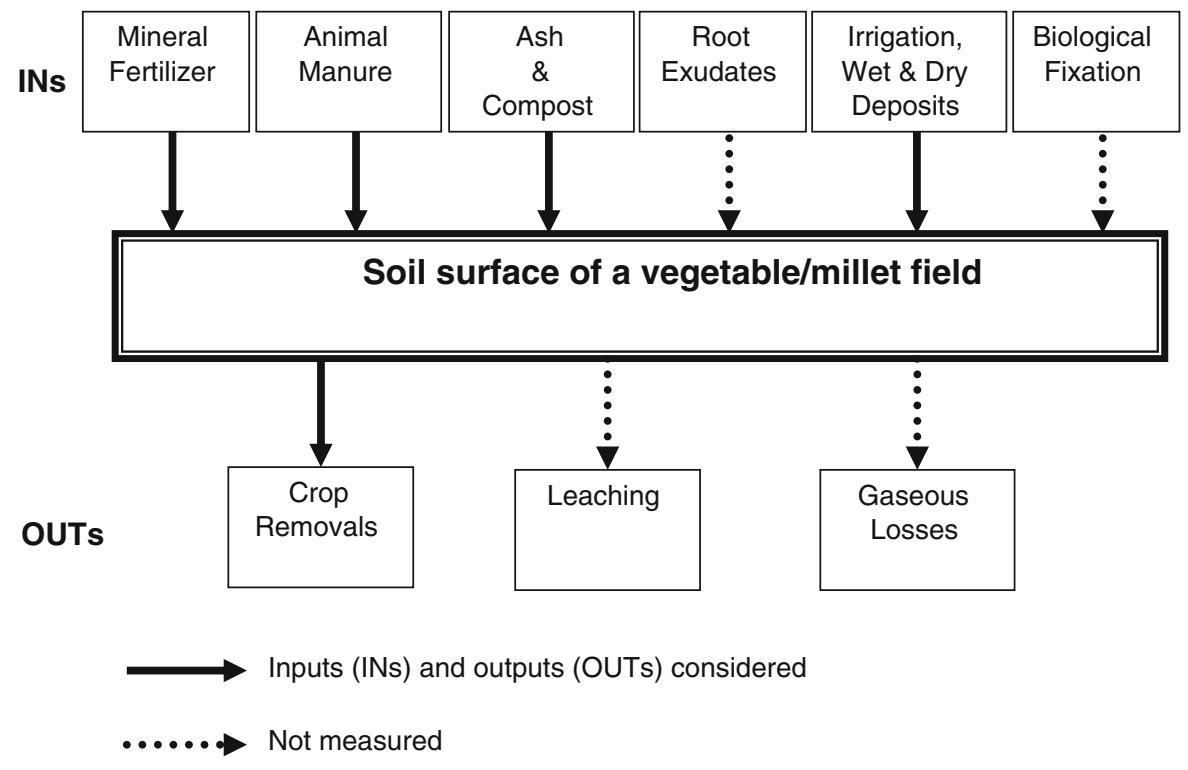

Fig. 1 Diagram showing the delineations of the soil surface partial horizontal balance (SSPHB) approach. Any application outside the double boundary was considered to be an external input into the SSPHB

detailed map produced from a 2005 Google Earth satellite image with $15 \mathrm{~m}$ resolution using ArcView 3.2. (Redlands, CA, USA).

\section{Quantification of horizontal nutrient fluxes}

Horizontal nutrient fluxes (inputs and outputs) related to farmers' management were measured in the selected gardens and millet fields over a period of 24 month (January 2006-January 2008). All study sites were visited at least once a week and farmers were interviewed about all relevant resources inputs onto and removals from the selected plots. The main sources of nutrient inputs included fertilizers (animal manure, mineral fertilizers, ash, compost), and irrigation water; wet and dry deposition and biological $\mathrm{N}$ fixation were accounted for using transfer functions. Moreover, carbon influx from root exudates were accounted for as they constitute an input flux for the organic $\mathrm{C}$ pool of the soil through the process termed rhizodeposition (Nguyen 2003). However, as root exudation is very difficult to quantify under field conditions (Dilkes et al. 2004), we assumed that root $\mathrm{C}$ influx was equivalent to harvested shoot $\mathrm{C}$.

In the gardens, fertilizer inputs were quantified throughout the cropping cycle by weighing the amounts applied. In the fields, the quantity of the predominantly used animal manure remaining on the soil after corralling of sheep, goats and/or cattle was determined before the onset of the rainy season using a sampling frame of $1 \mathrm{~m}^{2}$ with 10 repetitions per field. Representative samples of fertilizer and dung applied were taken at each application event (gardens) and sampling date (fields), respectively, and were kept for analysis of $\mathrm{C}, \mathrm{N}, \mathrm{P}$ and $\mathrm{K}$.

Different sources of irrigation water were used, namely, wastewater, pond water, well water and river water collected upstream and downstream of the city, depending on the location of the garden. Inputs from irrigation water were quantified on a weekly basis in the garden plots by counting the number of watering cans (8-17 l; volume determined in each case) used per day. The total amount of water applied was calculated from the quantity applied per day and the length of the cropping cycle and was multiplied by the nutrient concentration in the water source. Nutrient inputs through rainwater were calculated from the amount of rainfall measured by a rain gauge at $1.5 \mathrm{~m}$ above ground in each garden and the nutrient concentrations therein.

To quantify the outputs throughout the 24-months measurement period, the harvested biomass of all vegetables (except for minor quantities of medicinal or ornamental plants) was determined on the selected 
plots of each garden by either weighing the total crop harvested per plot or by sampling and weighing all material removed from two sampling areas of $1 \mathrm{~m}^{2}$ per plot and multiplied by the total area harvested. Samples were pooled by garden, harvest date, type of vegetable and fertilization treatment. In the fields, the grain and straw yield of millet and cowpea was quantified at harvest (October) on the selected plots, and representative samples were kept for the analysis of $\mathrm{C}, \mathrm{N}, \mathrm{P}, \mathrm{K}$. All samples of manure and harvested plant matter were oven-dried to constant weight at $65^{\circ} \mathrm{C}$ and ground to $1.5 \mathrm{~mm}$ particle size before chemical analysis using standard methods (see below).

Nutrient fluxes were estimated by multiplying the oven-dry mass of material by their nutrient concentrations using Eq. 1.

$F=\sum_{i=1}^{n} Q_{i} C_{i}$

where $F$ is the total nutrient flow (input or output) over the period of measurement, $n$ is the number of events (application of fertilizer, irrigation water, rain or crop removal, etc.), $Q_{i}$ is the quantity of raw material at event $i$ and $C_{i}$ is the nutrient concentration in the raw material at event $i$.

\section{Soil and water sampling}

To assess the status quo of soil fertility in each garden and field, soil samples were collected at $0-20 \mathrm{~cm}$ (garden and field) and 20-50 cm (fields only) depths using an auger. Two subsamples each taken from two different spots within the same plot were pooled to obtain a total of five samples per field and three samples per garden, thereby differentiating samples of differently managed plots. In the gardens, the samples were collected before crop fertilization and after 12 and 24 months of intense cultivation, while in the millet fields samples were collected before the onset of the rainy season in the first year (2006) and after the harvest in the first and in the second year (2007). Soil samples from fields were pooled by soil depth into one composite sample. All samples were air-dried on a clean paper within a few hours after sampling and analyzed for mineral $\mathrm{N}\left(\mathrm{NO}_{3}{ }^{-}\right.$and $\left.\mathrm{NH}_{4}{ }^{+}\right)$, Bray-P, $\mathrm{pH}$, organic carbon, effective cation exchange capacity (CEC), exchangeable $\mathrm{K}$ and total $\mathrm{N}$ using standard analytical techniques (see below).
For each garden on a bi-monthly basis $100 \mathrm{ml}$ of irrigation water were collected in duplicates from the watering cans or the source point. For rain water two samples were collected at one rainfall event in the beginning (July) and the middle of the rainy season (mid-August). After sampling, one drop of $0.1 \mathrm{~N} \mathrm{HCl}$ was added to each water sample after which samples were kept in the refrigerator at $4^{\circ} \mathrm{C}$ until analysis of $\mathrm{pH}, \mathrm{N}, \mathrm{P}$, and $\mathrm{K}$.

\section{Chemical analyses}

In soil, irrigation water and rainwater samples $\mathrm{pH}$ was determined in 1:2.5 soil:water (w:v) and water:water (v:v). In soil samples, organic carbon was determined according to the wet oxidation method (Walkley and Black 1934) and P-Bray according to Bray and Kurtz (1945). Total $\mathrm{N}$ and mineral $\mathrm{N}$ as nitrate $\left(\mathrm{NO}_{3}{ }^{-} \mathrm{N}\right)$ and ammonium $\left(\mathrm{NH}_{4}{ }^{+}-\mathrm{N}\right)$ were determined colorimetrically with an Alpkem Rapid Flow Analyzer (RFA 1985) at 520 and $660 \mathrm{~nm}$, respectively. Soil effective cation exchange capacity (ECEC) was determined by summation of exchangeable cations after their extraction with $1 \mathrm{n} \mathrm{NH}_{4}$-acetate and analysis of the extract by atomic absorption spectroscopy or flame emission spectro-photometry and of exchangeable acidity $\left(\mathrm{H}^{+}\right.$and $\left.\mathrm{Al}^{3+}\right)$ according to Espiau and Peyronel (1976). In manure, water and plant samples, total $\mathrm{N}$ was determined colorimetrically using the Bertholet reaction (Chaney and Marbach 1962) with an N-autoanalyzer (TECHNICON AAII, Ontario, Canada). Total $\mathrm{P}$ was also determined colorimetrically based on the phosphomolybdate complex reduced with ascorbic acid (Lowry and Lopez 1946) and K by flame photometry (Instrument Laboratory 543, CA, USA).

\section{Calculation of nutrient balances}

Soil surface nutrient budgets were compared to the change in extractable nutrients over the 24-months period using Eq. 2 proposed by Khai et al. (2007). To this end $\mathrm{C}, \mathrm{N}, \mathrm{P}$ and $\mathrm{K}$ partial balances were computed at the level of an individual field and garden by subtracting the nutrient outputs (through all harvested products) from the nutrient inputs.

$\Delta P_{\mathrm{E}}=I_{\mathrm{E}}-O_{\mathrm{E}}$

where $\Delta P_{\mathrm{E}}, I_{\mathrm{E}}$ and $O_{\mathrm{E}}$ stand for the change in the soil pool, the input and the output of element $E$, 
respectively. In our case, the equation takes into account the following inputs of element $\mathrm{E}$ from soil amendments: either organic or mineral fertilizer $\left(\mathrm{F}_{\mathrm{E}}\right)$, irrigation water $\left(\mathrm{IRW}_{\mathrm{E}}\right)$, wet plus dry depositions $\left(\mathrm{WD}_{\mathrm{E}}\right)$, biological nitrogen fixation $\left(\mathrm{BNF}_{\mathrm{E}}\right)$ and the outputs of $\mathrm{E}$ through harvested products $\left(\mathrm{HP}_{\mathrm{E}}\right)$. If also leaching losses $\left(\mathrm{L}_{\mathrm{E}}\right)$ and gaseous emissions $\left(\mathrm{GE}_{\mathrm{E}}\right)$ from the soil surface were accounted for, the net change in the soil storage $\left(\Delta \operatorname{Soil}_{\mathrm{E}}\right)$ of element $\mathrm{E}$ were calculated as:

$$
\begin{aligned}
\Delta \text { Soil }_{\mathrm{E}}= & \left.\mathrm{F}_{\mathrm{E}}+\mathrm{IRW}_{\mathrm{E}}+\mathrm{WD}_{\mathrm{E}}+\mathrm{BNF}_{\mathrm{E}}\right) \\
& -\left(\mathrm{HP}_{\mathrm{E}}+\mathrm{L}_{\mathrm{E}}+\mathrm{GE}_{\mathrm{E}}\right)
\end{aligned}
$$

However, leaching losses and gaseous emissions were only available for some of the studied gardens and fields (Predotova et al. 2010b); they were therefore not included in the nutrient flux equation. The apparent partial, that is horizontal, balance of element $\mathrm{E}$ thus resulted from Eq. 4:

$\Delta$ Soil $_{\mathrm{E}}=\mathrm{F}_{\mathrm{E}}+\mathrm{IRW}_{\mathrm{E}}+\mathrm{WD}_{\mathrm{E}}+\mathrm{BNF}_{\mathrm{E}}-\mathrm{HP}_{\mathrm{E}}$

For cowpea annual symbiotic $\mathrm{N}_{2}$-fixation was assumed to amount to $40 \mathrm{~kg} \mathrm{ha}^{-1}$ as it has been previously reported for the acid sandy soils of the Sahelian zone of Niger and total annual non-symbiotic $\mathrm{N}_{2}$-fixation was estimated at $5 \mathrm{~kg} \mathrm{ha}^{-1}$ (Roy et al. 2003). Yearly dry depositions of Harmattan dust were set at $1,200 \mathrm{~kg} \mathrm{ha}^{-1}$ with nutrient concentrations of $0.0038 \mathrm{~kg} \mathrm{~N} \mathrm{~kg}^{-1}$ dust, $0.00079 \mathrm{~kg} \mathrm{P} \mathrm{kg}^{-1}$ dust and $0.0187 \mathrm{~kg} \mathrm{~K} \mathrm{~kg}^{-1}$ dust (FAO 2005).

Vegetable contamination with pathogens and heavy metals

To assess a possible pathogen contamination of produced vegetables, two samples of irrigation water and of different leafy vegetables (cabbage, lettuceLactuca sativa L., and amaranth-Amaranthus cruentus L.) were aseptically (sterile equipment) collected per garden, once in the hot dry season (April 2007) and in the cool dry season (January 2008). Samples were kept in a refrigerator at $4^{\circ} \mathrm{C}$ after collection and composites per type of material and garden were analysed within $24 \mathrm{~h}$ for total mesophilic aerobic micro-organisms (Staphylococcus sp.) and for faecal pathogens of animal origin (Salmonella spp., Escherichia coli, Streptococci and total coliforms following standard procedures (APHA-AWWA-WEF 2001).
Additionally, irrigation water $(n=2)$ was sampled in each garden before (May) and after (October) the rains in 2006, and analysed for total concentrations of the heavy metals copper $(\mathrm{Cu})$, cadmium $(\mathrm{Cd})$, lead $(\mathrm{Pb})$, zinc $(\mathrm{Zn})$ and nickel (Ni) using Inductive Coupled Plasma Atomic Emission Spectrometry (ICP-AES, Spectro Analytical Instruments, Kleve, Germany; Heinrichs 1989).

Statistical analysis

For each plot, horizontal partial nutrient balances of $\mathrm{C}, \mathrm{N}, \mathrm{P}$, and $\mathrm{K}$ were converted to a hectare basis and $F$-tests performed using the General Linear Models (GLM) procedure within SAS 9.1 (SAS 2003). Independent variables were management intensity, season, and year, while dependent variables comprised soil chemical parameters, inputs and outputs of $\mathrm{C}, \mathrm{N}, \mathrm{P}$ and $\mathrm{K}$ as well as plant dry matter (DM) yields. Means were separated by $t$-tests (LSD) at $P=0.05$.

\section{Results}

Main characteristics of high and low input systems

In the high input vegetable gardens, annual total nutrient inputs ranged from 1,109 to $3,816 \mathrm{~kg} \mathrm{~N}$ $\mathrm{ha}^{-1}, 143$ to $644 \mathrm{~kg} \mathrm{P} \mathrm{ha}^{-1}$, and 640 to $2,019 \mathrm{~kg} \mathrm{~K}$ $\mathrm{ha}^{-1}$ as opposed to $198-782 \mathrm{~kg} \mathrm{~N} \mathrm{ha}^{-1}, 86-253 \mathrm{~kg} \mathrm{P}$ $\mathrm{ha}^{-1}$ and $315-898 \mathrm{~kg} \mathrm{~K} \mathrm{ha}^{-1}$ for low input gardens. Similarly, for high input millet fields annual total nutrient inputs varied from 87 to $173 \mathrm{~kg} \mathrm{~N}^{-1}, 19$ to $44 \mathrm{~kg} \mathrm{P} \mathrm{ha}^{-1}$ and 54 to $115 \mathrm{~kg} \mathrm{~K} \mathrm{ha}^{-1}$, while for low input millet fields annual nutrient inputs ranged from 0.1 to $11.4 \mathrm{~kg} \mathrm{~N} \mathrm{ha}^{-1}, 0.9$ to $5.6 \mathrm{~kg} \mathrm{P} \mathrm{ha}^{-1}$ and 13 to $21.9 \mathrm{~kg} \mathrm{~K} \mathrm{ha}^{-1}$.

Nutrient concentrations in irrigation and rain water

The use of wastewater for irrigation was most common in the gardens located along the wadi (Gountou Yena). This water contained, per litre, $150 \mathrm{mg} \mathrm{N}, 19 \mathrm{mg} \mathrm{P}$ and $66 \mathrm{mg} \mathrm{K}$ in the dry season (Fig. 2). In the rainy season, nutrient concentrations were 5-fold lower for N, 3-fold lower for P, and 50\% lower for K. For the other sources of irrigation water, 

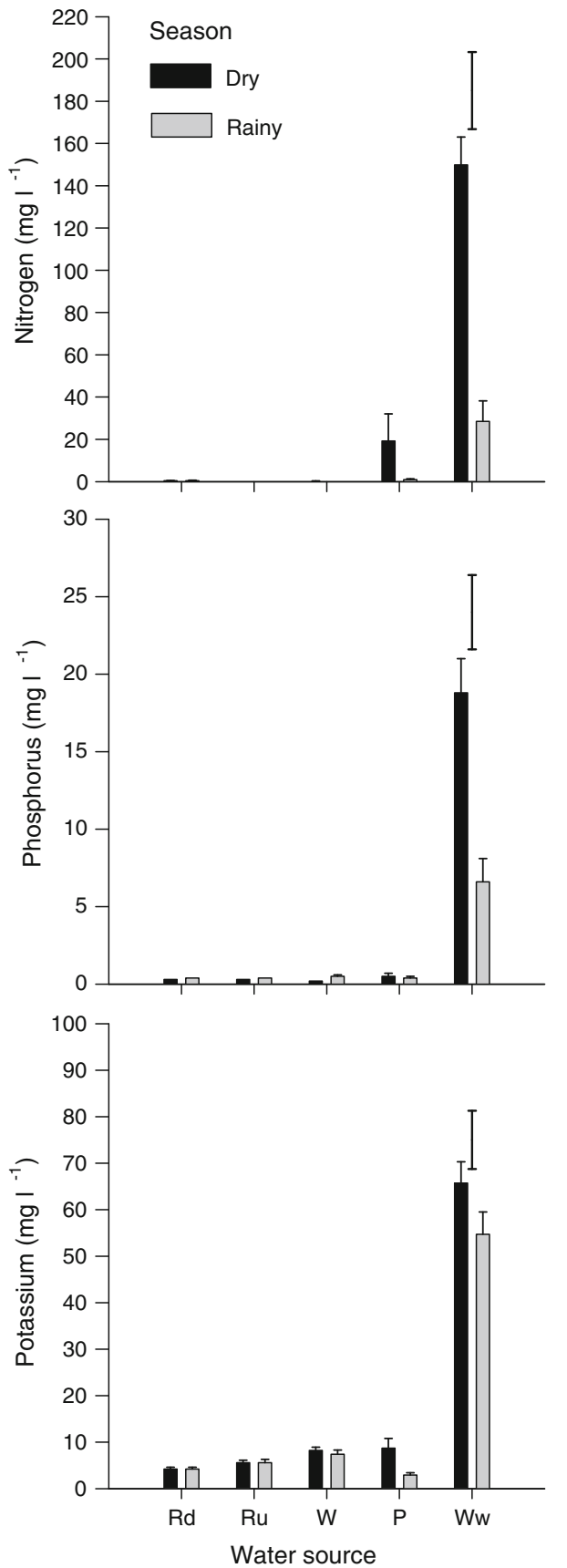

Fig. 2 Concentrations of nitrogen, phosphorus and potassium in different sources of irrigation water used in the vegetable gardens of Niamey, Niger. The number of gardens using each type of water are for downstream river (Rd): $n=3$, upstream river $(\mathrm{Ru}): n=3$, well $(\mathrm{W}): n=1$, pond $(\mathrm{P}): n=1$, and wastewater $(\mathrm{Ww}): n=2$. Two water samples were collected every 2 months in each garden during January 2006 to January 2008. Data represent annual averages plus one standard error. The isolated vertical lines indicate the least significant difference $\left(\mathrm{LSD}_{0.05}\right)$ of means for the two seasons however, seasonal differences in nutrient concentrations were not significant. For the dry season, the nutrient concentrations per litre of well, river (upstream and downstream), and pond water ranged from 0.2 to $19.2 \mathrm{mg} \mathrm{N}, 0.2$ to $0.5 \mathrm{mg} \mathrm{P}$ and 4.2 to $8.7 \mathrm{mg} \mathrm{K}$ as opposed to rainy season concentrations of $0.1-0.9 \mathrm{mg} \mathrm{N}, 0.4-0.5 \mathrm{mg} \mathrm{P}$ and $2.9-7.4 \mathrm{mg} \mathrm{K}$. Average nutrient concentrations in rain water were $0.03 \mathrm{mg} \mathrm{N}^{-1}, 0.20 \mathrm{mg} \mathrm{P}^{-1}$ and $3.77 \mathrm{mg} \mathrm{K}^{-1}$.

Horizontal nutrient balances in vegetable gardens

Nutrient inputs varied significantly between the high and the low input gardens. Mineral fertilizers were the major sources of $\mathrm{N}$ and $\mathrm{P}$ in the high input gardens, accounting for 48 and $80 \%$ of total $\mathrm{N}$ and $\mathrm{P}$ inputs, respectively. Average annual inputs through mineral fertilizers were $711 \mathrm{~kg} \mathrm{~N}^{-1}$ and $234 \mathrm{~kg} \mathrm{P}$ $\mathrm{ha}^{-1}$ in the high input gardens (Fig. 3) compared to $164 \mathrm{~kg} \mathrm{~N} \mathrm{ha}^{-1}$ and $25 \mathrm{~kg} \mathrm{P} \mathrm{ha}^{-1}$ in the low input gardens $(P<0.05)$. Application of livestock manure accounted for 44,61 and $75 \%$ of the total inputs of $\mathrm{N}$, $\mathrm{P}$ and $\mathrm{K}$, respectively, in the high input vegetable gardens, while it supplied $68 \% \mathrm{~N}, 73 \% \mathrm{P}$ and $48 \% \mathrm{~K}$ in the low input gardens. However, no significant differences were found between the two types of gardens as far as the amounts of nutrients applied with manure were concerned. Likewise, $\mathrm{C}$ influx through manure plus estimated deposits (root exudates assumed to be equivalent to harvested shoot $\mathrm{C}$ ) was similar for the two types of gardens (Fig. 3). Nutrient inflows through irrigation water were considerable, mainly for high input gardens where wastewater was used for irrigation, although the amounts of wastewater applied were lower than the amounts of water drawn from other water sources (Table 1). Due to its high nutrient concentrations it supplied annually up to $2,427 \mathrm{~kg} \mathrm{~N} \mathrm{ha}^{-1}, 376 \mathrm{~kg} \mathrm{P}$ ha $^{-1}$ and 1,439 $\mathrm{kg} \mathrm{K} \mathrm{ha}^{-1}$ (Fig. 2).

The total amounts of $\mathrm{C}, \mathrm{N}, \mathrm{P}$ and $\mathrm{K}$ exported through harvests in high input vegetable gardens significantly $(P<0.05)$ exceeded the exports in low input gardens (Table 3).

Given higher inputs of nutrients as compared to their removal with harvested produce, partial horizontal balances were strongly positive for both types of gardens. Average annual horizontal carbon and nutrient balances in high input vegetable gardens 

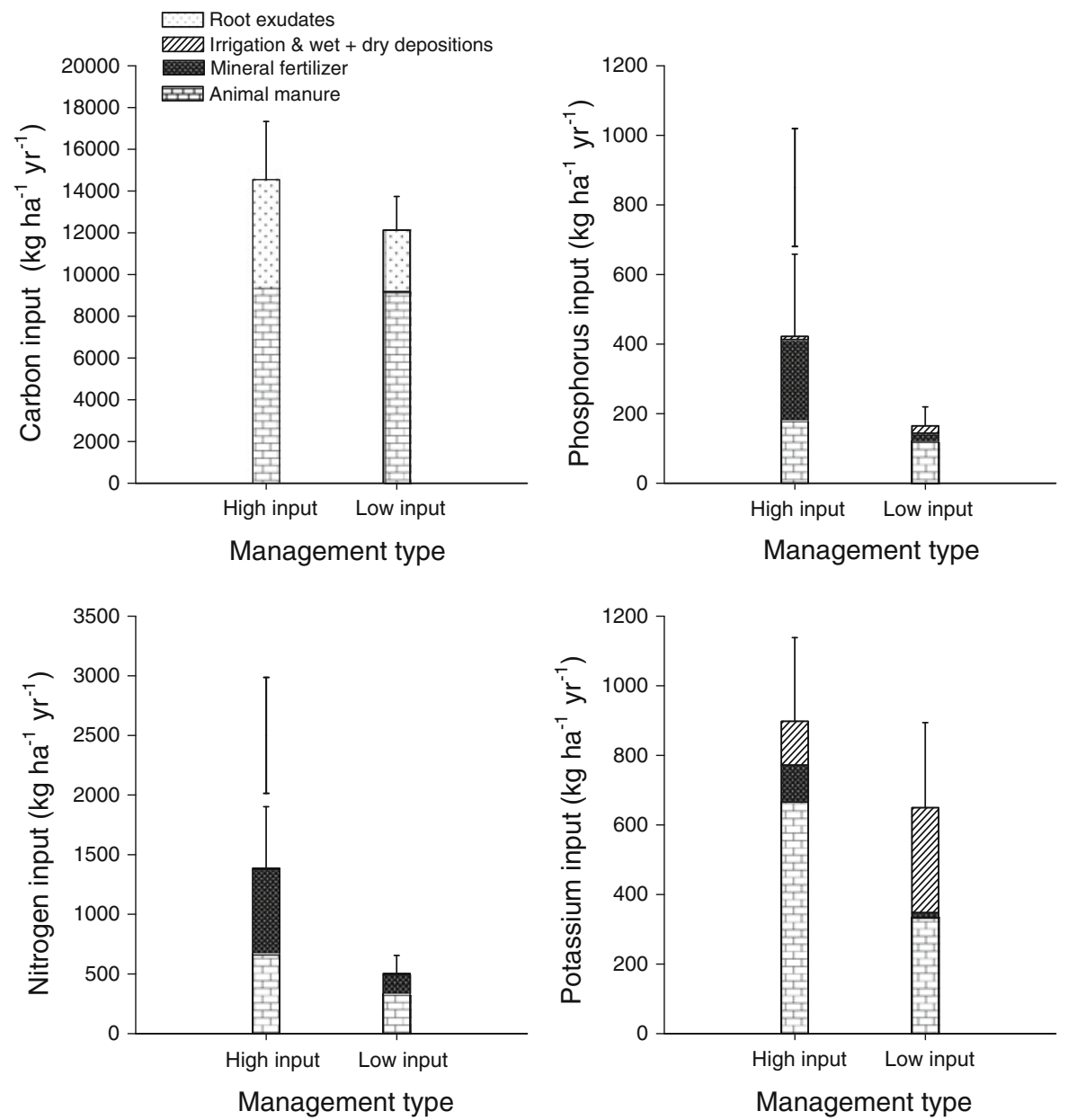

Fig. 3 Total amounts of carbon, phosphorus, nitrogen and potassium applied in high $(n=5)$ and low $(n=5)$ input vegetable gardens in Niamey, Niger, during January 2006 to January 2008. Data show annual means plus one standard error.

amounted to $9,936 \mathrm{~kg} \mathrm{C} \mathrm{ha}{ }^{-1}, 1,133 \mathrm{~kg} \mathrm{~N} \mathrm{ha}^{-1}$, $223 \mathrm{~kg} \mathrm{P} \mathrm{ha}^{-1}$ and $312 \mathrm{~kg} \mathrm{~K} \mathrm{ha}^{-1}$ as compared to $9,580 \mathrm{~kg} \quad \mathrm{C} \quad \mathrm{ha}^{-1} \quad(P>0.05), \quad 290 \mathrm{~kg} \mathrm{~N} \quad \mathrm{ha}^{-1}$ $(P<0.05), 125 \mathrm{~kg} \mathrm{P} \mathrm{ha}^{-1}(P>0.05)$ and $351 \mathrm{~kg} \mathrm{~K}$ $\mathrm{ha}^{-1}(P>0.05)$ in low input gardens (Fig. 4$)$.

The outputs (yields for one cycle of cultivation) obtained for the four major vegetables greatly depended on the crop type and the nutrient input rates. In high input gardens, the average amount of carbon and nutrients applied to cabbage $\left(\mathrm{kg} \mathrm{ha}^{-1}\right)$ was $5,613 \mathrm{~kg} \mathrm{C}, 949 \mathrm{~kg} \mathrm{~N}, 202 \mathrm{~kg} \mathrm{P}$ and $435 \mathrm{~kg} \mathrm{~K}$ per cropping cycle (85-days), while $7,515 \mathrm{~kg} \mathrm{C}$, $398 \mathrm{~kg} \mathrm{~N}, 103 \mathrm{~kg} \mathrm{P}$ and $416 \mathrm{~kg} \mathrm{~K}$ were applied to tomato for each 3-month cropping cycle. The

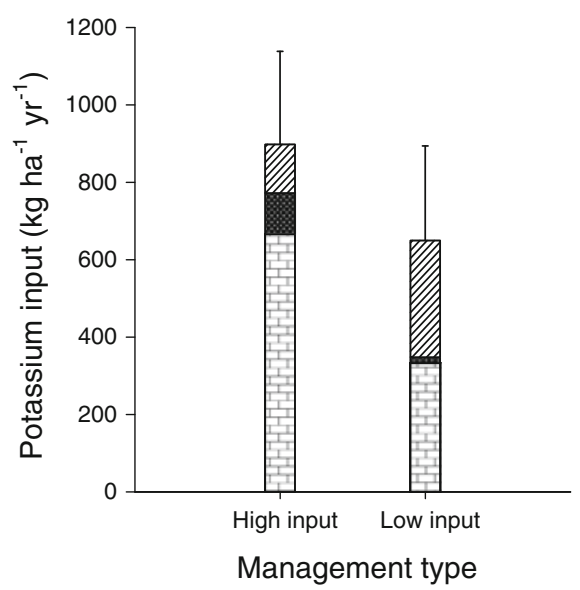

The isolated vertical lines indicate the least significant difference $\left(\mathrm{LSD}_{0.05}\right)$ of means for the two management systems. Carbon input resulted from manure and estimated deposits from root exudates

resulting yields were $8 \mathrm{t} \mathrm{DM} \mathrm{ha}^{-1}$ of cabbage and $0.6 \mathrm{t} \mathrm{DM} \mathrm{ha}^{-1}$ of tomato, which exceeded the yields in low input gardens by a factor of 3.8 and 6.0, respectively (Table 4). Carbon and nutrients applied to lettuce ( $\mathrm{kg} \mathrm{ha}^{-1}$, per 1.5-month cropping cycle) amounted to $5,260 \mathrm{~kg} \mathrm{C}, 173 \mathrm{~kg} \mathrm{~N}, 52 \mathrm{~kg} \mathrm{P}$ and $195 \mathrm{~kg} \mathrm{~K}$ in low input gardens and were $50 \%$ lower for $\mathrm{C}$ and $\mathrm{P}$ and about 3-fold lower for $\mathrm{N}$ and 2-fold lower for $\mathrm{K}$, compared to high input gardens. For amaranth, nutrient application $\left(\mathrm{kg} \mathrm{ha}^{-1}\right.$, per month of cropping cycle) averaged $81 \mathrm{~kg} \mathrm{~N}, 5 \mathrm{~kg} \mathrm{P}$ and $122 \mathrm{~kg} \mathrm{~K}$ in low input gardens as opposed to $531 \mathrm{~kg} \mathrm{~N}, 73 \mathrm{~kg} \mathrm{P}$ and $300 \mathrm{~kg} \mathrm{~K}$ in high input gardens. Regardless of management intensity, no 
Table 3 Vegetable crop cycles during the study period ( $n$ and (SD)), cumulative yields ( $\mathrm{t} \mathrm{DM} \mathrm{ha}{ }^{-1} 2$ year $^{-1}$ ) and average amounts $\left(\mathrm{kg} \mathrm{ha}^{-1}\right.$, one cycle) of nitrogen $(\mathrm{N})$, phosphorus $(\mathrm{P})$ and potassium $(\mathrm{K})$ removed with the edible parts of four vegetables cultivated in low and high input vegetable gardens of Niamey, Niger, from January 2006 to January 2008

\begin{tabular}{llllrrr}
\hline $\begin{array}{l}\text { Vegetable } \\
\text { gardens }\end{array}$ & Vegetable & $\begin{array}{l}\text { Crop } \\
\text { cycles }\end{array}$ & Yield & $\mathrm{N}$ & $\mathrm{P}$ & $\mathrm{K}$ \\
\hline $\begin{array}{l}\text { High input } \\
(n=5)\end{array}$ & Lettuce & $10.7(10)$ & 25.6 & 83 & 14 & 173 \\
& Cabbage & $5.8(4)$ & 46.4 & 260 & 54 & 286 \\
& Amaranth & $19.0(11)$ & 45.6 & 98 & 15 & 154 \\
& Tomato & $3.0(1)$ & 1.8 & 16 & 3 & 35 \\
Low input & Lettuce & $6.4(4)$ & 16.6 & 67 & 14 & 158 \\
$(n=5)$ & Cabbage & $2.5(1)$ & 5.3 & 49 & 12 & 93 \\
& Amaranth & 1 & 6.3 & 202 & 32 & 376 \\
& Tomato & 1 & 0.1 & 3 & 1 & 9 \\
\hline
\end{tabular}

\begin{tabular}{llcll}
\hline & \multicolumn{4}{l}{ Cumulative nutrient export } \\
\cline { 2 - 5 } & Total C & Total N & Total P & Total K \\
\hline High input & 59,895 & 4,306 & 757 & 6,541 \\
Low input & 14,176 & 756 & 157 & 1,629 \\
\hline
\end{tabular}

Also shown are cumulative nutrient and carbon exports $\left(\mathrm{kg} \mathrm{ha}^{-1} 2\right.$ year $\left.^{-1}\right)$

All nutrient outputs are specified in Fig. 1

$D M$ dry matter

organic amendments were applied to amaranth (Table 4). For both vegetables, yields in low input gardens amounted to $2.6 \mathrm{t} \mathrm{DM} \mathrm{ha}^{-1}$ (lettuce) and $6.3 \mathrm{t}$ $\mathrm{DM} \mathrm{ha}^{-1}$ (amaranth) per cropping cycle, as compared to $2.4 \mathrm{t} \mathrm{DM} \mathrm{ha}^{-1}$ for lettuce and amaranth, respectively, in high input gardens.

Horizontal nutrient balances in millet fields

Animal manure was the main source of nutrient inputs to millet fields, applied annually at an average rate of $10.3 \mathrm{tDM} \mathrm{ha}^{-1}(\mathrm{SD}=3.8)$ in high input fields, thereby supplying $129 \mathrm{~kg} \mathrm{~N} \mathrm{ha}^{-1}, 25 \mathrm{~kg} \mathrm{P} \mathrm{ha}^{-1}$ and $62 \mathrm{~kg} \mathrm{~K}$ $\mathrm{ha}^{-1}$. Manure application accounted for 76, 91 and $65 \%$ of total $\mathrm{N}, \mathrm{P}$ and $\mathrm{K}$ inputs in high input fields. Additional nutrient inputs originated from mineral fertilizers, which were, however, applied at low rates (Table 1). At an average of $1.5 \mathrm{t} \mathrm{DM} \mathrm{ha}^{-1}(\mathrm{SD}=0.2)$ the annual amount of manure applied to low input fields was significantly lower $(P<0.05)$, supplying only $7 \mathrm{~kg} \mathrm{~N} \mathrm{ha}^{-1}, 3 \mathrm{~kg} \mathrm{P} \mathrm{ha}^{-1}$ and $7 \mathrm{~kg} \mathrm{~K} \mathrm{ha}^{-1}$ (Fig. 5).
Annual $\mathrm{C}$ inputs through manure plus the estimated root deposition (root debris and exudates) amounted to $1,723 \mathrm{~kg} \mathrm{ha}^{-1}$ in high input as opposed to 1,014 $\mathrm{kg} \mathrm{ha}^{-1}$ in low input millet fields. In low input fields, calculated wet plus dry depositions supplied up to $93 \%$ of the $\mathrm{K}$ inputs as compared to calculated $39 \%$ in high input fields. Additional $\mathrm{N}$ inputs to the fields might have resulted from the unquantified $\mathrm{N}_{2}$-fixation of cowpea intercropped with millet in both management systems. However, this contribution to horizontal balances is likely to be $<20 \mathrm{~kg} \mathrm{ha}^{-1}$ given the low stand density of cowpea in all monitored fields (1,000-2,000 plants ha $\left.{ }^{-1}\right)$. Annual N removals through harvest of cowpea shoots and hay averaged $6.8 \mathrm{~kg} \mathrm{ha}^{-1}(\mathrm{SD}=5.7)$ in high input fields and accounted for $16 \%$ of the total $\mathrm{N}$ exports, while in low input fields the average removal of $5.8 \mathrm{~kg} \mathrm{~N}^{-1}$ $(\mathrm{SD}=4.9)$ accounted for $27 \%$ of total $\mathrm{N}$ exports. Nutrient removals from high input millet fields through millet grain and stover harvest exceeded those from low input fields for all nutrients studied (Table 5). During the 2 years cumulative $\mathrm{C}$ and nutrient exports were 1.5-fold higher for $\mathrm{C}$ and $\mathrm{P}, 2.4$-fold higher for $\mathrm{N}$ and 3-fold higher for $\mathrm{K}$ in the high input gardens compared to the low input gardens.

In the millet fields about $20-25 \%$ of the stalks were left on the field after harvest while up to $80 \%$ was removed and used as animal feed at the homestead. Horizontal balances were positive for C, $\mathrm{N}, \mathrm{P}$ and $\mathrm{K}$ in high input fields with annual carbon and nutrient surpluses of $259 \mathrm{~kg} \mathrm{C} \mathrm{ha}^{-1}, 125 \mathrm{~kg} \mathrm{~N}$ $\mathrm{ha}^{-1}, 20 \mathrm{~kg} \mathrm{P}^{-1}$ and $0.4 \mathrm{~kg} \mathrm{~K} \mathrm{ha}^{-1}$, and differed significantly $(P<0.05$ for $\mathrm{C}, \mathrm{N}, \mathrm{P}$ only) from those of low input fields (Fig. 6).

In contrast, in low input fields, horizontal balances were negative for $\mathrm{P}$ and $\mathrm{K}$ and only slightly positive for $\mathrm{C}$ and $\mathrm{N}$.

Millet stover and grain yields strongly varied with the year and management intensity. In 2006, stover and grain yields averaged 2,932 $\mathrm{kg} \mathrm{DM} \mathrm{ha}^{-1}$ and $644 \mathrm{~kg}$ $\mathrm{DM} \mathrm{ha}^{-1}$ in high input fields versus $821 \mathrm{~kg} \mathrm{DM} \mathrm{ha}^{-1}$ for stover and $167 \mathrm{~kg} \mathrm{DM} \mathrm{ha}^{-1}$ for grain in low input fields. However, in 2007, the yields obtained in high input fields were lower $\left(2,603 \mathrm{~kg} \mathrm{DM} \mathrm{ha}^{-1}\right.$ for stover and $614 \mathrm{~kg} \mathrm{DM} \mathrm{ha}^{-1}$ for grain), while stover $(1,723 \mathrm{~kg}$ $\mathrm{DM} \mathrm{ha}^{-1}$ ) and grain (451 kg DM ha ${ }^{-1}$ ) yields were higher in low input fields compared to the previous year. 

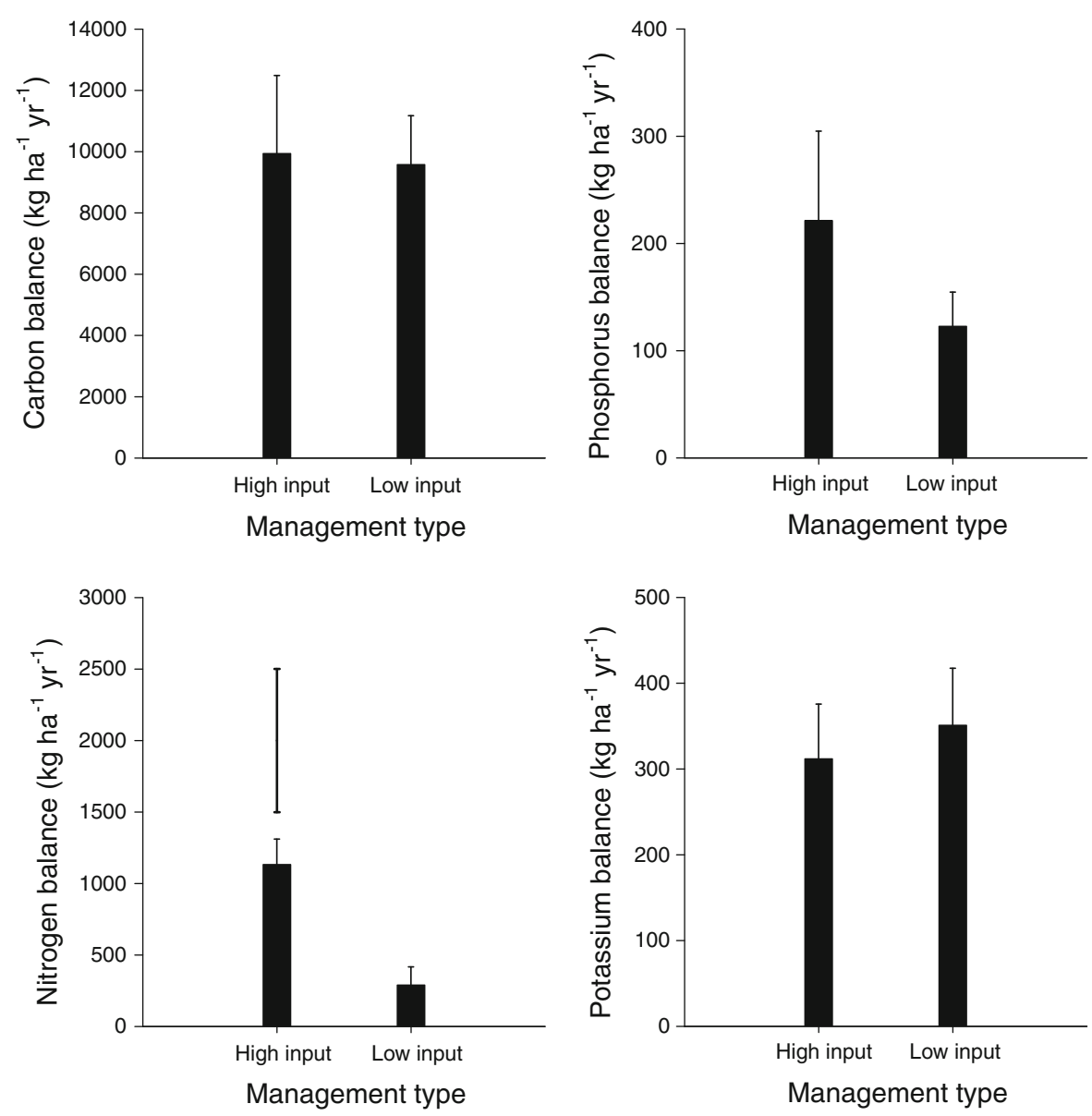

Fig. 4 Annual partial horizontal balances of carbon, phosphorus, nitrogen and potassium in high $(n=5)$ and low $(n=5)$

to January 2008. Data show means plus one standard error. The isolated vertical lines indicate the least significant difference $\left(\mathrm{LSD}_{0.05}\right)$ of means for the two management systems

Table 4 Amounts $\left(\mathrm{kg} \mathrm{ha}^{-1}\right.$; mean \pm one standard error) of carbon $(\mathrm{C})$ nitrogen $(\mathrm{N})$, phosphorus $(\mathrm{P})$ and potassium $(\mathrm{K})$ applied to four major vegetables during one cropping cycle and

the respective yields ( $\mathrm{DM} \mathrm{ha}^{-1}$; mean \pm one standard error) in high and low input vegetable gardens of Niamey, Niger

\begin{tabular}{lllcccc}
\hline Vegetable garden & Vegetable & Yield & C & N & P & K \\
\hline High input $(n=5)$ & Lettuce & $2.4 \pm 0.2$ & $5561 \pm 1123$ & $474 \pm 62$ & $73 \pm 9$ & $355 \pm 36$ \\
& Cabbage & $8.0 \pm 0.9$ & $5613 \pm 446$ & $949 \pm 204$ & $202 \pm 59$ & $435 \pm 81$ \\
& Amaranth & $2.4 \pm 0.2$ & - & $531 \pm 94$ & $73 \pm 19$ & $300 \pm 30$ \\
& Tomato & $0.6 \pm 0.2$ & $7515 \pm 1817$ & $398 \pm 138$ & $103 \pm 37$ & $416 \pm 122$ \\
Low input $(n=5)$ & Lettuce & $2.6 \pm 0.2$ & $5260 \pm 1051$ & $173 \pm 29$ & $52 \pm 8$ & $195 \pm 24$ \\
& Cabbage & $2.1 \pm 0.6$ & $5783 \pm 1278$ & $91 \pm 10$ & $40 \pm 4$ & $164 \pm 9$ \\
& Amaranth $^{\text {a }}$ & 6.3 & - & 81 & 34 & 5 \\
& Tomato $^{\text {a }}$ & 0.1 & 3587 & & 21 & 122 \\
\hline
\end{tabular}

All nutrient sources are specified in Fig. 1

$D M$ dry matter

a Only one garden was recorded where standard errors do not appear

- In both management systems animal manure is not applied to amaranth 

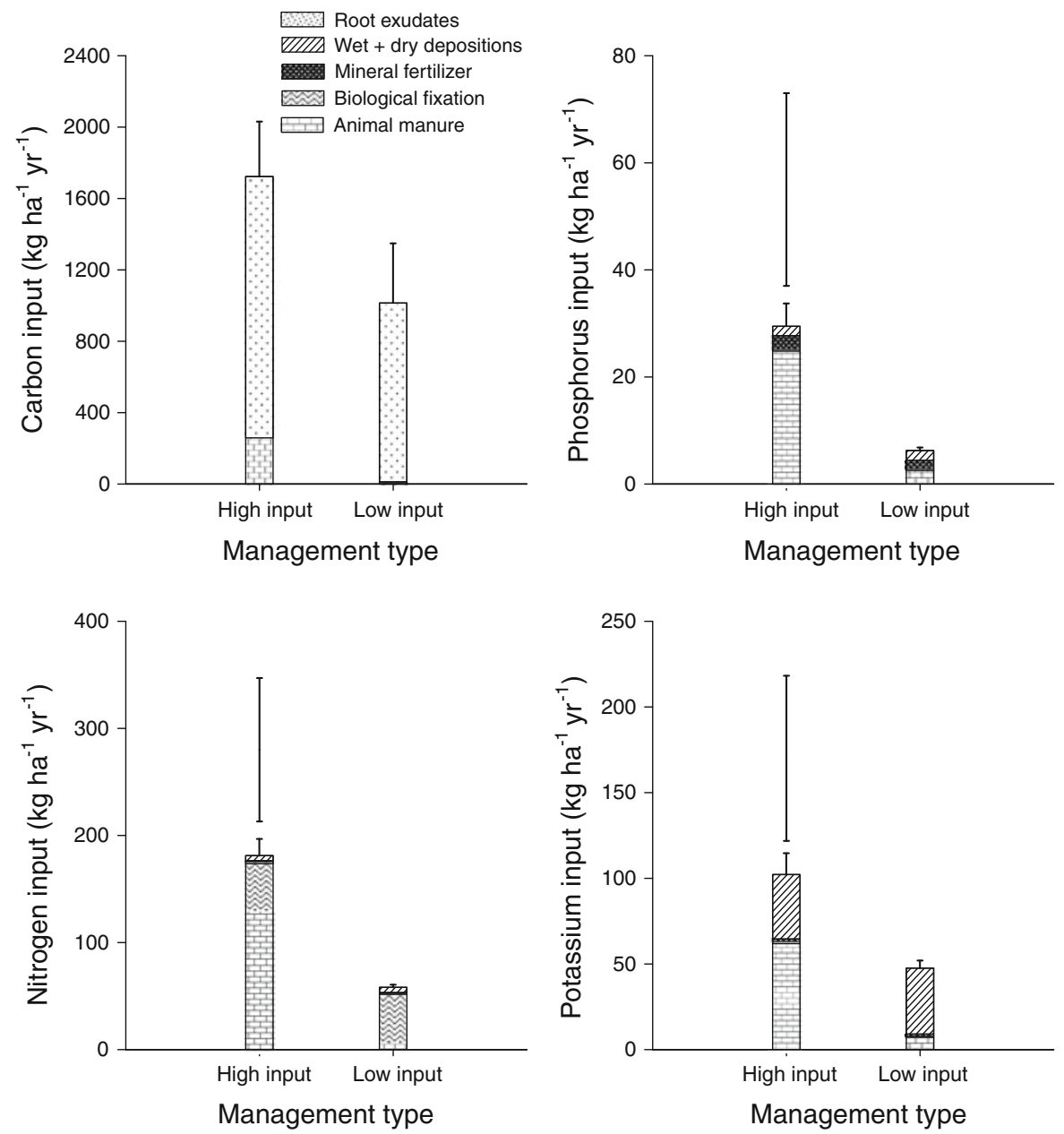

Fig. 5 Annual total amounts of carbon, phosphorus, nitrogen and potassium applied to high $(n=5)$ and low $(n=4)$ input millet fields in Niamey, Niger, during January 2006 to January 2008. Data show means plus one standard error. The isolated

Changes in the soil nutrient pool and chemical properties of vegetable gardens and millet fields

In high input gardens, average soil $\mathrm{pH}$ was 7.1 $(\mathrm{SD}=0.5)$ in 2006 , remained unchanged in 2007 and decreased to $6.7(\mathrm{SD}=0.7)$ in $2008(P>0.05)$. In low input gardens, no changes in soil $\mathrm{pH}$ were observed throughout the study period (Table 6). Millet soils had a much lower $\mathrm{pH}$ than those of vegetable gardens, but no significant changes were observed in the topsoil and subsoil $\mathrm{pH}$ of millet fields during the study period. In high input gardens soil Corg increased by $36 \%$ from $4.9 \mathrm{~g} \mathrm{~kg}^{-1}(\mathrm{SD}=1.8)$ in 2006 to $7.6 \mathrm{~g} \mathrm{~kg}^{-1}(\mathrm{SD}=5.3)$ in 2008 , while during the same period it decreased by a factor of 1.2

vertical lines indicate the least significant difference $\left(\mathrm{LSD}_{0.05}\right)$ of means for the two management systems. Carbon input resulted from manure and estimated deposits from root exudates

in low input gardens; a similar trend was determined for soil total $\mathrm{N}$ (Table 6). However, none of these changes was statistically significant. In the millet fields soil Corg remained unchanged over the 2-year study period.

In soils of vegetable gardens available nutrients increased over the study period, notably for exchangeable $\mathrm{K}(P>0.05)$ and Nmin $(P<0.05$, except for $\left.\mathrm{NO}_{3}{ }^{-}-\mathrm{N}\right)$. The concentrations of $\mathrm{NH}_{4}{ }^{+}-\mathrm{N}$ determined in soils of high input gardens were 53 times higher in 2008 than in 2006, while $\mathrm{NO}_{3}{ }^{-}-\mathrm{N}$ decreased by a factor of 7 during the same period. In low input gardens, soil $\mathrm{NH}_{4}{ }^{+}-\mathrm{N}$ increased by a factor of 9 between the start and the end of the study period, while $\mathrm{NO}_{3}{ }^{-}-\mathrm{N}$ slightly decreased (Table 6). In high 
Table 5 Average millet grain and stover yields $\left(\mathrm{kg} \mathrm{DM} \mathrm{ha}^{-1} \mathrm{year}^{-1}\right)$ and amounts $\left(\mathrm{kg} \mathrm{ha}^{-1}\right.$ year $\left.^{-1}\right)$ of nitrogen $(\mathrm{N})$, phosphorus $(\mathrm{P})$ and potassium $(\mathrm{K})$ removed from low and high input millet fields near Niamey, Niger, from January 2006 to January 2008

\begin{tabular}{|c|c|c|c|c|}
\hline \multirow[t]{2}{*}{ Millet system } & \multicolumn{2}{|l|}{ Grain } & \multicolumn{2}{|l|}{ Stover } \\
\hline & $\begin{array}{l}\text { High input } \\
(n=5)\end{array}$ & $\begin{array}{l}\text { Low input } \\
(n=4)\end{array}$ & $\begin{array}{l}\text { High input } \\
(n=5)\end{array}$ & $\begin{array}{l}\text { Low input } \\
(n=4)\end{array}$ \\
\hline Dry matter & 630 & 289 & 2767 & 1122 \\
\hline $\mathrm{N}$ & 13.5 & 6.3 & 34.2 & 10.0 \\
\hline $\mathrm{P}$ & 3.3 & 1.7 & 5.0 & 1.8 \\
\hline \multirow[t]{3}{*}{ K } & 7.6 & 5.4 & 107.4 & 24.5 \\
\hline & \multicolumn{4}{|c|}{ Cumulative nutrient exports } \\
\hline & Total C & Total N & Total P & Total K \\
\hline High input & 2,928 & 78 & 14 & 187 \\
\hline Low input & 2,004 & 32 & 9 & 62 \\
\hline
\end{tabular}

Also shown are cumulative nutrient and carbon exports $\left(\mathrm{kg} \mathrm{ha}^{-1} 2 \mathrm{year}^{-1}\right)$

All nutrient inputs and outputs are specified in Fig. 1

$D M$ dry matter

input millet systems, a 55\% decrease of $\mathrm{NH}_{4}{ }^{+}-\mathrm{N}$ was determined in the surface soil and a similar trend was observed for $\mathrm{NO}_{3}{ }^{-}-\mathrm{N}$. In the subsoil $\mathrm{NH}_{4}{ }^{+}-\mathrm{N}$ increased by $16 \%$, while $\mathrm{NO}_{3}{ }^{-}-\mathrm{N}$ decreased by $57 \%$. In contrast, no major changes in available soil $\mathrm{N}$ were observed in low input millet systems. Over the 2-year study period, soil concentrations of P-Bray decreased significantly in the high input and slightly in the low input gardens. Effective CEC increased significantly in vegetable gardens while no changes were found in millet fields (Table 6).

Contamination of water and vegetables

with pathogens and heavy metals

Irrigation water from the river, ponds, and wastewater sources were contaminated with Staphylococcus aureus and other pathogens mainly in the cool dry but also the hot dry season, whereby the level of contamination was higher in wastewater than in the other water sources (Table 7). The outer leaves of vegetables such as amaranth, lettuce and cabbage irrigated with river water or wastewater were contaminated with Salmonella spp. as well as with E. coli. In cabbage irrigated with wastewater and river water as well as in amaranth irrigated with wastewater, total mesophilic aerobic microorganism counts exceeded $10^{6} \mathrm{CFU} \mathrm{g}{ }^{-1}$ fresh matter in the hot dry season and were thus above the threshold value recommended by
CNERNA (1996). However, in the cool dry season, pathogen levels were low in lettuce and cabbage (Table 8). Although Salmonella spp. counts in the wastewater used in garden Gountou Yena 1 amounted to $5 \times 10^{2} \mathrm{CFU} 100 \mathrm{ml}^{-1}$ in the hot dry season, no contamination was determined in cabbage leaves. In the cool dry season Salmonella spp. counts in this water source were 12 -fold higher $\left(6 \times 10^{3} \mathrm{CFU} 100 \mathrm{ml}^{-1}\right)$, and the irrigated lettuce harbored the pathogens at a concentration of $9.8 \times 10^{4} \mathrm{CFU} 25 \mathrm{~g}^{-1}$ fresh matter of the leaves. In the irrigated garden Gountou Yena 2, amaranth and cabbage leaves were contaminated with Salmonella spp. in the hot dry and cool dry season even though no pathogens were detected in the wastewater used for irrigation (Table 8). In the cool dry season, lettuce leaves irrigated with river water were also contaminated with Salmonella spp. in the gardens Yantala Bas 1, Yantala Bas 2 and Nogare 2, and with E. coli in the gardens Yantala Bas 2 and Saga (Table 8).

In the hot dry season of 2006, the concentration $\left(\mathrm{mg} \mathrm{l}^{-1}\right)$ of heavy metals upstream and downstream of the Niger River ranged from 0.00 to 0.02 for $\mathrm{Zn}$, 0.01 to 0.03 for $\mathrm{Cu}$ and 0.01 to 0.01 for $\mathrm{Ni}$. In the wastewater running through the wadi, the respective concentrations varied from 0.03 to 0.11 for $\mathrm{Zn}, 0.03$ to 0.04 for $\mathrm{Cu}$ and 0.01 for $\mathrm{Ni}$. In pond water $\mathrm{Zn}, \mathrm{Cu}$ and $\mathrm{Ni}$ concentrations averaged 0.16, 0.12 and 0.04 , respectively (Table 9). Shortly after the rainy season 2006, no Ni was detected in any of the water sources, 

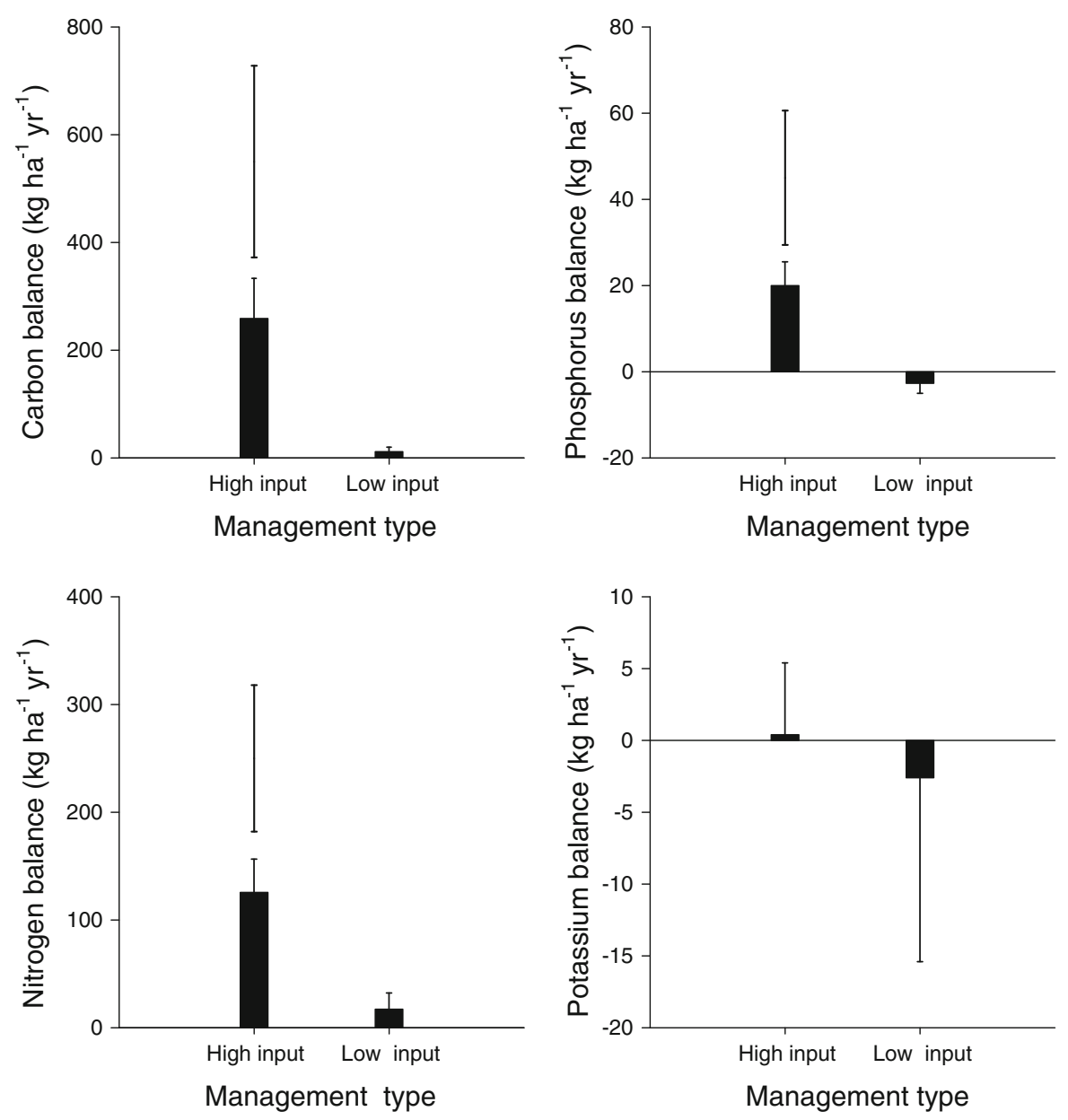

Fig. 6 Annual partial horizontal balances of carbon, phosphorus, nitrogen and potassium in high $(n=5)$ and low $(n=4)$

January 2008. Data show means plus one standard error. The isolated vertical lines indicate the least significant difference $\left(\mathrm{LSD}_{0.05}\right)$ of means for the two management systems

and only traces of $\mathrm{Zn}$ were present in river and pond water, while for wastewater the $\mathrm{Zn}$ concentration ranged from 0.02 to $0.04 \mathrm{mg} \mathrm{l}^{-1}$. Post rainy season $\mathrm{Cu}$ concentration in upstream and downstream river water was $0.01 \mathrm{mg} \mathrm{l}^{-1}$, while values of $0.01-0.02$ $\mathrm{mg}^{-1}$ were determined for wastewater and 0.01 $\mathrm{mg} \mathrm{l}^{-1}$ for pond water (Table 9).

\section{Discussion}

Horizontal nutrient balances

in vegetable gardens

The management practices in Niamey's UPA vegetable gardens were characterized by large nutrient inputs

from mineral fertilizers and livestock manure to which in some cases high nutrient inputs from wastewater irrigation added. Similar observations were reported for the vegetable systems in and around Kumasi, Ghana, where local application rates of poultry manure amounted to 20-50 $\mathrm{t} \mathrm{ha}^{-1}$ year $^{-1}$ for cabbage and 50$100 \mathrm{t} \mathrm{ha}^{-1}$ year $^{-1}$ for lettuce and spring onion (Allium spp.), equivalent to annual inputs of $770-1,650 \mathrm{~kg} \mathrm{~N}$ $\mathrm{ha}^{-1}, 420-900 \mathrm{~kg} \mathrm{P}^{-1}$ and $350-750 \mathrm{~kg} \mathrm{~K} \mathrm{ha}^{-1}$ (Drechsel et al. 2004). Similarly large application rates of organic $\left(>40 \mathrm{t} \mathrm{ha}^{-1}\right.$ ) and mineral (360-1150 $\mathrm{kg} \mathrm{ha}^{-1}$ ) fertilizers to African eggplant and amaranth were reported for UPA systems of Cotonou, Benin (Assogba-Komlan et al. 2007).

While in high input gardens of Niamey application rates per cropping cycle to cabbage and lettuce 


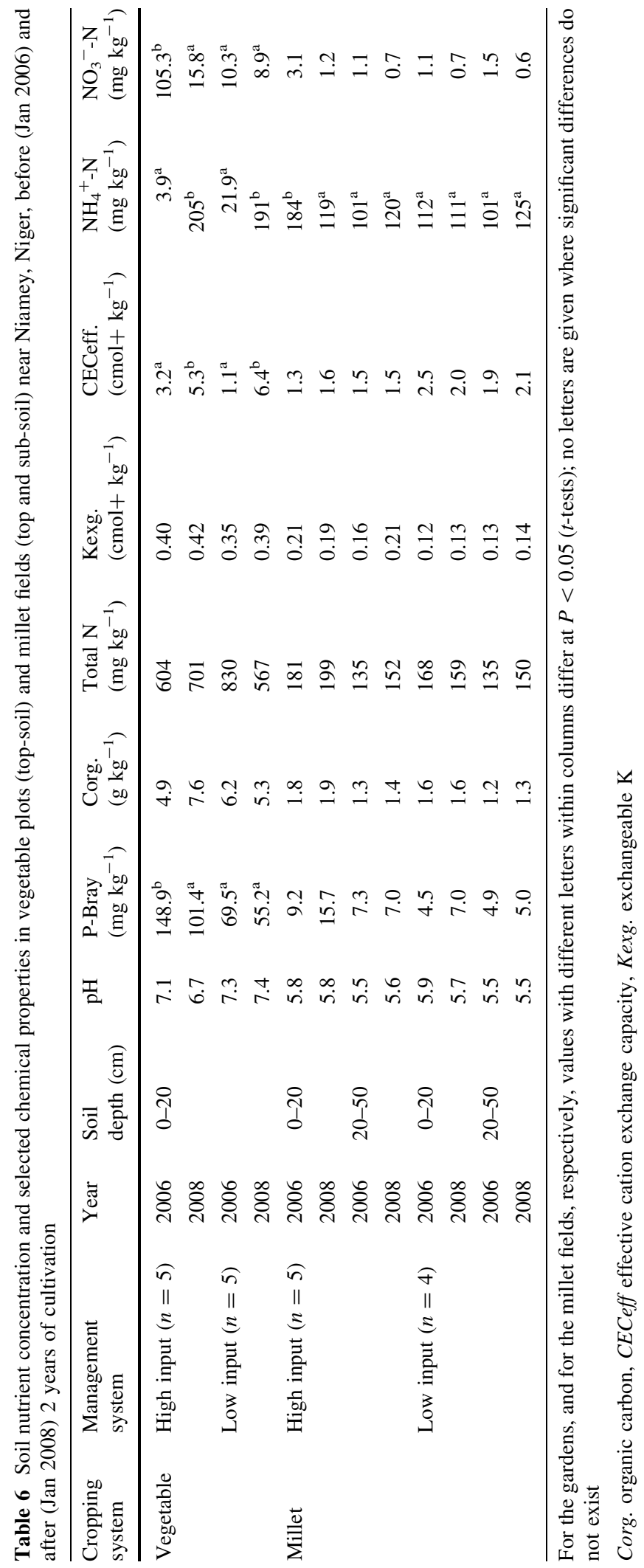


Table 7 Total counts of microbial cells in irrigation water used in vegetable gardens in Niamey, Niger, during the hot and cool dry season 2007

\begin{tabular}{|c|c|c|c|c|c|c|c|}
\hline Season & Garden & $\begin{array}{l}\text { Water } \\
\text { source }\end{array}$ & $\begin{array}{l}\text { Total coliforms } \\
\left(\mathrm{CFU} 100 \mathrm{ml}^{-1}\right)\end{array}$ & $\begin{array}{l}\text { E. coli } \\
\text { (CFU } \\
\left.100 \mathrm{ml}^{-1}\right)\end{array}$ & $\begin{array}{l}\text { Salmonella } \\
(\mathrm{CFU} \\
\left.100 \mathrm{ml}^{-1}\right)\end{array}$ & $\begin{array}{l}\text { Faecal } \\
\text { Streptococci } \\
\left(\text { CFU } 100 \mathrm{ml}^{-1}\right)\end{array}$ & $\begin{array}{l}\text { Staphylococcus } \\
\text { aureus } \\
\left(\mathrm{CFU} 100 \mathrm{ml}^{-1}\right)\end{array}$ \\
\hline \multirow[t]{3}{*}{ Hot dry } & Saga & Niger river & None & n.d. & None & None & n.d. \\
\hline & Gountou Yena 1 & Wastewater 'wadi' & $15 \times 10^{2}$ & n.d. & $5 \times 10^{2}$ & $27 \times 10^{2}$ & n.d. \\
\hline & Gountou Yena 2 & Wastewater 'wadi' & $88 \times 10^{4}$ & n.d. & None & None & n.d. \\
\hline \multirow[t]{8}{*}{ Cool dry } & Tondibia Gorou & Pond & n.d. & None & None & n.d. & $0.3 \times 10^{5}$ \\
\hline & Yantala Bas 1 & Niger river & n.d. & None & None & n.d. & $1.4 \times 10^{5}$ \\
\hline & Yantala Bas 2 & Niger river & n.d. & None & None & n.d. & $4.9 \times 10^{5}$ \\
\hline & Nogare 1 & Niger river & n.d. & None & None & n.d. & $0.6 \times 10^{5}$ \\
\hline & Nogare 2 & Niger river & n.d. & None & None & n.d. & $3.3 \times 10^{5}$ \\
\hline & Saga & Niger river & n.d. & None & None & n.d. & $3.2 \times 10^{5}$ \\
\hline & Gountou Yena 1 & Wastewater 'wadi' & n.d. & None & $6 \times 10^{3}$ & n.d. & $26 \times 10^{5}$ \\
\hline & Gountou Yena 2 & Wastewater 'wadi' & n.d. & $2 \times 10^{5}$ & None & n.d. & $21 \times 10^{5}$ \\
\hline
\end{tabular}

CFU colony forming units; $n . d$. not determined, specific counts were not performed

Table 8 Total counts of microbial cells on cabbage, amaranth and lettuce irrigated from different water sources in Niamey, Niger, during the hot and cool dry season 2007, and internationally recommended threshold values

\begin{tabular}{|c|c|c|c|c|c|c|}
\hline Season & Garden & Water source & Vegetable & $\begin{array}{l}\text { Total mesophilic } \\
\text { aerobic micro-organisms } \\
\left(\mathrm{CFU} \mathrm{g}^{-1}\right)\end{array}$ & $\begin{array}{l}\text { E. coli } \\
\left(\mathrm{CFU} \mathrm{g}{ }^{-1}\right)\end{array}$ & $\begin{array}{l}\text { Salmonella } \\
\left(\mathrm{CFU} 25 \mathrm{~g}^{-1}\right)\end{array}$ \\
\hline \multirow[t]{3}{*}{ Hot dry } & Saga & Niger river & Cabbage & $>10^{6}$ & None & None \\
\hline & Gountou Yena 1 & Wastewater 'wadi' & Cabbage & $>10^{6}$ & None & None \\
\hline & Gountou Yena 2 & Wastewater 'wadi' & Amaranth & $>10^{6}$ & None & $3 \times 10^{6}$ \\
\hline \multirow[t]{8}{*}{ Cool dry } & Tondibia Gorou & Pond & Lettuce & $0.58 \times 10^{5}$ & None & None \\
\hline & Yantala Bas 1 & Niger river & Lettuce & $2.58 \times 10^{5}$ & None & $8.7 \times 10^{4}$ \\
\hline & Yantala Bas 2 & Niger river & Lettuce & $1.46 \times 10^{5}$ & $2.0 \times 10^{4}$ & $0.9 \times 10^{4}$ \\
\hline & Nogare 1 & Niger river & Lettuce & $0.13 \times 10^{5}$ & None & None \\
\hline & Nogare 2 & Niger river & Lettuce & $1.27 \times 10^{5}$ & None & $11.9 \times 10^{4}$ \\
\hline & Saga & Niger river & Lettuce & $1.58 \times 10^{5}$ & $5.8 \times 10^{4}$ & None \\
\hline & Gountou Yena 1 & Wastewater 'wadi' & Lettuce & $0.68 \times 10^{5}$ & $0.6 \times 10^{4}$ & $9.8 \times 10^{4}$ \\
\hline & Gountou Yena 2 & Wastewater 'wadi' & Cabbage & $7.63 \times 10^{5}$ & $0.2 \times 10^{4}$ & $3.5 \times 10^{4}$ \\
\hline \multicolumn{4}{|c|}{ CNERNA standard } & $<5 \times 10^{5}$ & $\leq 10$ & Absent \\
\hline \multicolumn{4}{|c|}{ ICSMF standard } & $10^{6}<X<5 \times 10^{7}$ & $\leq 10$ & Absent \\
\hline
\end{tabular}

CNERNA (1996)

ICMSF (1974)

CFU colony forming units

ranged from 10 to $30 \mathrm{t} \mathrm{ha}^{-1}$ for animal manure, 43 to $1,771 \mathrm{~kg} \mathrm{ha}^{-1}$ for urea and 120 to $628 \mathrm{~kg} \mathrm{ha}^{-1}$ for NPK (15:15:15), application rates in low input gardens were $9-28 \mathrm{t} \mathrm{ha}^{-1}$ for animal manure,
$38-278 \mathrm{~kg} \mathrm{ha}^{-1}$ for urea and $55-252 \mathrm{~kg} \mathrm{ha}^{-1}$ for NPK. The high application rates of urea, NPK and livestock dung and the addition of high amounts of $\mathrm{N}$ through wastewater in some gardens caused large $\mathrm{N}$ 


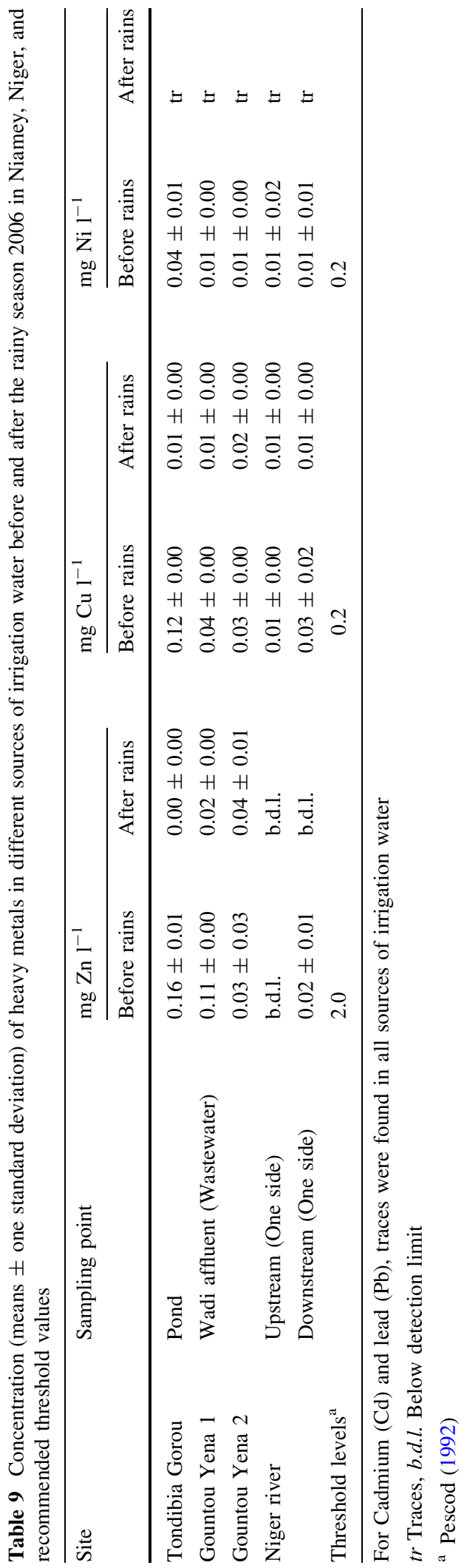

surpluses in high input gardens. Although the latter allowed for nutrient extractions in harvested products that were more than 4-fold higher than in low input gardens, nutrient uptake varied greatly among the crops grown and was particularly high for leafy vegetables such as lettuce, cabbage and amaranth. With an average of $45 \mathrm{tha}^{-1}$ of fresh matter (FM) per cropping cycle, the yield of lettuce in low input gardens corresponded well to the value of $39 \mathrm{t} \mathrm{FM}$ $\mathrm{ha}^{-1}$ reported for similar production systems elsewhere (Khai et al. 2007), and was substantially higher than the 15-20 $\mathrm{t} \mathrm{FM} \mathrm{ha}^{-1}$ reported by PSEAU (2007) for Niamey at a dung application of 15-25 $\mathrm{t} \mathrm{ha}^{-1}$. Moreover, average cabbage yields of $25 \mathrm{t} \mathrm{FM} \mathrm{ha}^{-1}$ recorded in low input gardens were within the range of 10-40 t FM ha ${ }^{-1}$ reported by PSEAU (2007), while average yields of $97 \mathrm{t} \mathrm{FM} \mathrm{ha}^{-1}$ obtained in high input gardens were far above this range.

Annual surpluses of $223 \mathrm{~kg} \mathrm{P}^{-1}$ and $312 \mathrm{~kg} \mathrm{~K}$ $\mathrm{ha}^{-1}$ were calculated for high input gardens in Niamey. These figures compared well to horizontal balances reported for intensively managed smallscale vegetable systems in Hanoi, Vietnam, for which annual surpluses of $109-196 \mathrm{~kg} \mathrm{P} \mathrm{ha}^{-1}$ and 20$306 \mathrm{~kg} \mathrm{~K} \mathrm{ha}^{-1}$ were published by Khai et al. (2007). However, at $1,133 \mathrm{~kg} \mathrm{ha}^{-1}$ the average annual $\mathrm{N}$ surplus in Niamey by far exceeded the $85-882 \mathrm{~kg} \mathrm{~N}$ $\mathrm{ha}^{-1}$ balance reported for Hanoi (Khai et al. 2007). Despite the highly positive $\mathrm{N}$ balance over the 2-year study period, no significant changes in total soil $\mathrm{N}$ contents were found. This may be due to gaseous and leaching losses of $\mathrm{N}$, particularly as urea and manure were often not incorporated into the topsoil immediately after application. In a companion study of UPA gardens in Niamey, annual losses of $92 \mathrm{~kg} \mathrm{~N} \mathrm{ha}^{-1}$ in the form of $\mathrm{NH}_{3}$ and $\mathrm{N}_{2} \mathrm{O}$ were reported, with particularly high emission rates at the end of the dry season and the start of the first rains (Predotova et al. 2010a). For the same gardens, the average annual leaching losses were estimated at $11.4 \mathrm{~kg} \mathrm{~N} \mathrm{ha}^{-1}$, $1.2 \mathrm{~kg} \mathrm{P} \mathrm{ha}^{-1}$ and $24.9 \mathrm{~kg} \mathrm{~K} \mathrm{ha}^{-1}$ (Predotova et al. 2010b).

To estimate total annual balances of $\mathrm{C}, \mathrm{N}, \mathrm{P}$ and $\mathrm{K}$ for intensively managed gardens in Niamey, the above mentioned gaseous and leaching losses were used and complemented by annual $\mathrm{CO}_{2}-\mathrm{C}$ and $\mathrm{CH}_{4}-\mathrm{C}$ losses of $27 \mathrm{t} \mathrm{C} \mathrm{ha}^{-1}$ (Predotova et al. 2010a). The resulting average annual total balances were with $843 \mathrm{~kg} \mathrm{~N} \mathrm{ha}^{-1}, 70 \mathrm{~kg} \mathrm{P} \mathrm{ha}^{-1}$ and $200 \mathrm{~kg} \mathrm{~K} \mathrm{ha}^{-1}$ still 
strongly positive for these major plant nutrients, which was in contrast to a $\mathrm{C}$ deficit of $-26 \mathrm{t} \mathrm{ha}^{-1}$ reflecting high mineralisation rates of organic matter. While such a negative $\mathrm{C}$ balance points to the need of maintaining high rates of manure application, the input of mineral fertilizer could be substantially reduced, which would lower production costs and increase resource use efficiency of UPA vegetable production in Niamey. This is all the more important since in the high input vegetable gardens a decrease in soil $\mathrm{pH}$ has been observed during the 24 months of our study, which may be due to the high rates of mineral $\mathrm{N}$ application and related leaching losses and may in the long run have negative consequences on $\mathrm{P}$ availability. A decrease in soil $\mathrm{pH}$ by 1.4 units was reported for intensive production of broccoli (Brassica oleracea var. silvestris L.) in the USA with surface application of ammonium nitrate, leading to increased nitrification and soil acidification (Stamatiadis et al. 1999). Similarly, excessive N application has been reported to increase topsoil acidification in tomato (Solanum lycopersicum L.) and maize (Zea mays L.) fields (Dougill et al. 2002; Ju et al. 2007) and to cause yield reductions in tomato (Badr and Talaab 2008) and summer cabbage (Smith and Hadley 1992). The substantial accumulation of Nmin, notably $\mathrm{NH}_{4}{ }^{+}$in the topsoil of both high and low input vegetable systems may reflect residual $\mathrm{N}$ surpluses and increase the acidification of the topsoil. The observed Nmin increases in the topsoil may indicate $\mathrm{NO}_{3}{ }^{-}-\mathrm{N}$ accumulation in the cultivated leafy vegetables. However, this would need verification. Pôrto et al. (2008) reported such increases in leaf, stem and roots of lettuce with increased application levels of urea and cattle manure.

Horizontal nutrient balances in peri-urban millet fields

In peri-urban millet production, partial nutrient balances were strongly positive for high input fields. In low inputs fields, $\mathrm{P}$ and $\mathrm{K}$ mining occurred as nutrient removal through harvested millet and cowpea grain and stover by far exceeded the very low input levels applied to these subsistence crops. This compares well to earlier reports about typical rural millet cultivation in SW Niger (Bationo and Buerkert 2001). The strongly positive horizontal balances in high input millet fields resulted mainly from manure application at an average annual rate of $10.3 \mathrm{t} \mathrm{DM} \mathrm{ha}{ }^{-1}$ through corralling of sheep, goats and cattle, which reflects the often close agro-pastoral linkages in low-intensity land use systems of Niger. Such agro-pastoral linkages were also reported for millet systems in northern Burkina Faso (Quilfen and Milleville 1983; Berger et al. 1987) and underline the role of livestock for the cereal farming systems in the Sahelian zone. To minimize nutrient leaching on sandy Sahelian soils, Brouwer and Powell (1998) recommended not to exceed an annual manure application rate of $2.5 \mathrm{t} \mathrm{DM}$ $\mathrm{ha}^{-1}$. In the present study the annual quantity of manure applied to the high input fields was 4-fold higher than this amount and by the same magnitude lower than amounts determined in high input vegetable gardens. The stover yields obtained in low input fields $\left(1,122 \mathrm{~kg} \mathrm{DM} \mathrm{ha}^{-1}\right.$ year $\left.^{-1}\right)$ compared well to average millet stover yields in the Sahel (1,390 kg DM $\mathrm{ha}^{-1}$ year $^{-1}$ ) reported by Yamoah et al. (2002), but were lower than the $1,625 \mathrm{~kg} \mathrm{DM} \mathrm{ha}{ }^{-1}$ year $^{-1}$ published for an on-station experiment in Niger where $2.5 \mathrm{t} \mathrm{DM} \mathrm{ha}^{-1}$ year $^{-1}$ of manure were applied (Akponikpe et al. 2008). The grain yields obtained in the studied high input millet fields $\left(630 \mathrm{~kg} \mathrm{DM} \mathrm{ha}{ }^{-1}\right.$ year $^{-1}$ ) were also lower than the $964 \mathrm{~kg} \mathrm{DM} \mathrm{ha}{ }^{-1}$ year $^{-1}$ reported for farmers' fields in Niger receiving $10 \mathrm{t} \mathrm{DM} \mathrm{ha}^{-1}$ year $^{-1}$ of manure (Schlecht et al. 2004), an input similar to the amount applied to millet fields of our study. These findings provide evidence for the poor resource use efficiency in Niamey's peri-urban millet production. Predotova et al. (2010a) reported average annual losses of $17 \mathrm{~kg} \mathrm{~N} \mathrm{ha}^{-1}$ as $\mathrm{NH}_{3}$ and $\mathrm{N}_{2} \mathrm{O}$ and of $5,765 \mathrm{~kg} \mathrm{C}^{-1}$ as $\mathrm{CH}_{4}$ and $\mathrm{CO}_{2}$ from Niamey's UPA millet fields, accompanied by annual leaching losses of $3.6 \mathrm{~kg} \mathrm{~N}^{-1}$ and $2.7 \mathrm{~kg} \mathrm{P} \mathrm{ha}^{-1}$ (Predotova et al. 2010b). Taking into account these gaseous and leaching losses, total annual balances for an intensively managed UPA millet field were estimated at $-4.8 \mathrm{t} \mathrm{C} \mathrm{ha}^{-1}, 118 \mathrm{~kg} \mathrm{~N}^{-1}, 17 \mathrm{~kg} \mathrm{P}$ $\mathrm{ha}^{-1}$ and $95 \mathrm{~kg} \mathrm{~K} \mathrm{ha}^{-1}$. The latter three values are more than twice the total annual balances of $25 \mathrm{~kg} \mathrm{~N}$ $\mathrm{ha}^{-1}, 7.8 \mathrm{~kg} \mathrm{Pha}^{-1}$ and $24.1 \mathrm{~kg} \mathrm{~K} \mathrm{ha}^{-1}$ calculated for millet fields in Niger that received $2.5 \mathrm{t} \mathrm{DM} \mathrm{ha}^{-1}$ of manure (Akponikpe et al. 2008). Provided that sufficient family labour is available, farmers might thus be advised to redirect the available manure from high input fields into low input fields, so as to increase the overall productivity and efficiency of peri-urban millet production. 
Contamination of water and vegetables

with pathogens and heavy metals

The low amount of mesophilic aerobic microorganisms in the wastewater samples collected during the cool dry season might have been due to dilution effects which had occurred during the rainy season. Possible sources of Staphylococcus aureus in irrigation water are air-borne particles deposited by sandstorms or Harmattan dust, human excreta and skin abrasions, since this pathogen is closely associated with nasal secretions of humans (Bremer et al. 2004). The presence of Streptococci, E. coli and Salmonella in the wastewater is an indication of faecal contamination, which is an issue of general concern when untreated wastewater is used for irrigation. A study in El Azouzzia, Morocco, showed that lettuce and parsley (Petroselinum crispum var. neapolitanum) irrigated with untreated wastewater were contaminated with the same serogroups of Salmonella B and C that were identified in the water source (Melloul et al. 2001). It is evident that the particularities of a crop species and its consumption patterns (e.g. lettuce versus carrot, Daucus carota subsp. sativus) largely determine the level of and risk for bacterial transmission to the consumer. A recent Salmonella spp. risk assessment study showed that human infection strongly depends on the type of crop, irrigation method, and most importantly the number of days elapsed between the last irrigation and consumption (Stine et al. 2005). The presence of E. coli on lettuce at Yantala Bas 1, Nogare 2 and Gountou Yena 1 may be due to the application of only partially composted ruminant manure in these gardens which is another possible source of contamination. This application practice is quite common in the UPA of Niamey where farmers broadcast manure on the standing crop. A contamination of lettuce with faecal coliforms originating from poultry manure was previously reported from Accra and Kumasi (Ghana), independently of the type of irrigation water used (Drechsel et al. 2000; Amoah et al. 2005). These reports show that health risk assessments should not be limited to the quality of the irrigation water, but also address alternative pathways of vegetable contamination such as by animal manure and soil splash. Recent studies in Kumasi showed that in the dry season the avoidance of lettuce irrigation with wastewater six days before harvest effectively reduced microbial contamination of this important UPA produce (Keraita et al. 2007). Similar results were reported from Yuma, Arizona, where iceberg lettuce subjected to early termination of irrigation showed reduced microbial counts (Jorge 2006). However, in Niger this measure seems to be inefficient in the wet season, and it might adversely affect the productivity and freshness of vegetables in the dry season, thereby decreasing farmers' profits. Therefore, an integrated approach targeting all farmrelevant contamination sources apart from irrigation water and manure is required. Further studies should determine the survival conditions of Salmonella spp. and $E$. coli in the soil and manure stacks under the Sahelian conditions, so as to derive more environmentally safe dung management strategies, thereby reducing health risks for vegetable consumers. The concentrations of $\mathrm{Zn}, \mathrm{Cu}$ and $\mathrm{Ni}$ in all water sources were far below the established threshold values for irrigation water estimated at $2 \mathrm{mg} \mathrm{Zn} 1^{-1}, 0.2 \mathrm{mg} \mathrm{Cu}$ $1^{-1}$ and $0.2 \mathrm{mg} \mathrm{Ni}^{-1}$ (Pescod 1992) and for vegetables set at $50 \mathrm{mg} \mathrm{Zn} \mathrm{kg}^{-1}$ dry weight (DW), $30 \mathrm{mg} \mathrm{Cu} \mathrm{kg}{ }^{-1} \mathrm{DW}$ and $1.5 \mathrm{mg} \mathrm{Ni} \mathrm{kg}{ }^{-1} \mathrm{DW}$ (Awashthi 2000). The difference between the low heavy metal concentrations found in our study and

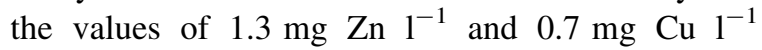
reported for the same water sources by Graefe et al. (2008) is most likely due to a difference in sampling location. Our samples were collected at the gardeners' points of water withdrawal for crop irrigation, which were located a few $100 \mathrm{~m}$ downstream of the source points used by Graefe et al. (2008), leading to dilution effects. In previous UPA studies crop irrigation with sewage water and industrial effluents, application of municipal solid wastes and lavish pesticide usage have been identified as the main sources for toxic levels of heavy metals, mainly $\mathrm{Zn}$ and $\mathrm{Ni}$, on lettuce (171 and $52 \mathrm{mg} \mathrm{kg}^{-1} \mathrm{DM}$ ), spinach (Spinacia oleracea L., 154 and $69 \mathrm{mg} \mathrm{kg}^{-1}$ DM) and radish (Raphanus sativus L., 139 and $63 \mathrm{mg} \mathrm{kg}^{-1} \mathrm{DM}$ ), respectively (Awashthi 2000; Binns et al. 2003; Gupta et al. 2008). In Lagos, Nigeria, concentrations of $106 \mathrm{mg} \mathrm{Cu} \mathrm{kg} \mathrm{ma}^{-1}$ and $25 \mathrm{mg} \mathrm{Ni} \mathrm{kg}{ }^{-1}$ were found in (dried) soil of industrial areas as opposed to $63 \mathrm{mg} \mathrm{Cu} \mathrm{kg}{ }^{-1}$ and $13 \mathrm{mg} \mathrm{Ni}$ $\mathrm{kg}^{-1}$ in residential areas (Yusuf et al. 2003). Vegetables such as water leaf (Talinum triangulare J.), bush okra (Corchorus olitorus L.), bitter leaf (Vernonia amygdalina L.) and fluted pumpkin (Telfairia 
occidentalis $\mathrm{H}$.) cultivated in the industrial areas accumulated significantly higher amounts of $\mathrm{Cu}$ and $\mathrm{Ni}$ than those cultivated in the residential areas (Yusuf et al. 2003). In Titagarh, West Bengal, India, mean concentrations of $1.9 \mathrm{~g} \mathrm{Zn}^{-1}, 1.6 \mathrm{~g} \mathrm{Cu}^{-1}$ and $0.7 \mathrm{~g} \mathrm{Ni}^{-1}$ were reported for untreated wastewater used for irrigation. These were leading to soil concentrations of $217 \mathrm{mg} \mathrm{Zn} \mathrm{kg}{ }^{-1}, 90 \mathrm{mg} \mathrm{Cu} \mathrm{kg}{ }^{-1}$ and $104 \mathrm{mg} \mathrm{Ni} \mathrm{kg}^{-1}$ and resulted in subsequent accumulation of these metals in vegetables far beyond recommended threshold values (Gupta et al. 2008). Given the low industrial development of Niamey, the accumulation of metal elements in irrigated vegetables seems at present of only minor concern.

\section{Conclusions}

The findings of this study indicate that UPA vegetable and millet production in Niamey are characterized by poor nutrient use and management:

(i) large surpluses of $\mathrm{N}, \mathrm{P}$ and $\mathrm{K}$ were observed in vegetable gardens of low and high input intensity but $\mathrm{C}$ balances remain critical and require recycling of manure to maintain soil $\mathrm{C}$ levels;

(ii) in peri-urban millet cultivation, surpluses of $\mathrm{N}$ (for high and low input fields), $\mathrm{P}$ and $\mathrm{K}$ (high input fields only) prevailed, however, mining of $\mathrm{P}$ and $\mathrm{K}$ was shown for low input fields;

(iii) the observed surpluses were derived from a wide range of sources whose contribution varied among sites. In the vegetable gardens, mineral fertilizers accounted for $34-48 \%$ of N , 15-80\% of $\mathrm{P}$ and $2-12 \%$ of $\mathrm{K}$ inputs. Animal manure contributed $69-79 \%$ to the $\mathrm{C}$ input, $44-68 \%$ to $\mathrm{N}, 61-73 \%$ to $\mathrm{P}$ and $48-75 \%$ to $\mathrm{K}$. In the millet fields manure contributed significantly to the positive partial nutrient balances and accounted for $13-76 \%$ of N, 79-91\% of P and 17-65\% of K inputs, while root exudates were estimated to contribute 85-99\% of the C inputs. Atmospheric deposition contributed mainly to the $\mathrm{K}$ input and biological $\mathrm{N}_{2}$-fixation to the $\mathrm{N}$ input.

The results of this study suggest that there is a scope for improved nutrient use efficiency and management in Niamey's UPA systems. To achieve this, strategies that better match nutrient supply to crop demand need to be applied. Pre-treatment of wastewater prior to use for irrigation and application of composted animal dung will contribute to minimize produce contamination, $\mathrm{NO}_{3}{ }^{-}$leaching and ammonia volatilisation and to enhance food safety, thereby reducing the negative externalities of UPA on the environment and human health.

Acknowledgements We are grateful to I. Kadaoré for mapping Niamey's UPA gardens and fields, and to Dr. A. Ayantunde, Dr. D. Fatondji and M. Diolombi (ICRISAT Sahelian Centre, Niamey, Niger) for scientific advice and logistic support. We also thank the UPA farmers of Niamey for their patience and collaboration and the Deutsche Forschungsgemeinschaft (DFG) for financial support of this study.

Open Access This article is distributed under the terms of the Creative Commons Attribution Noncommercial License which permits any noncommercial use, distribution, and reproduction in any medium, provided the original author(s) and source are credited.

\section{References}

Akegbejo-Samsons Y (2008) Impact of urban agriculture on water reuse and related activities on the rural population of the coastal settlements of Ondo state, Nigeria. Afr J Food Agric Nutr Dev 8(1):48-62

Akponikpe PBI, Michels K, Bielders CL (2008) Integrated nutrient management of pearl millet in the Sahel combining cattle manure, crop residue and mineral fertilizer. Exp Agric 44:453-472

Amoah P, Drechsel P, Abaidoo RC (2005) Irrigated urban vegetable production in Ghana: sources of pathogen contamination and health risk examination. J Irrig Drain 54:49-61

APHA-AWWA-WEF (2001) Standard methods for the examination of water and wastewater, 22nd edn. Washington, DC

Assogba-Komlan F, Anihouvi P, Achigan E, Sikirou R, Boko A, Adje C, Ahle V, Vodouhe R, Assa A (2007) Pratiques culturales et teneur en éléments anti-nutritionnels (nitrates et pesticides) du Solanum macrocarpum au sud du Bénin. Afr J Food Agric Nutr Dev 7:1-21

Awashthi SK (1954) Prevention of food Adulteration Act no 37 of 1954. Central and state rules as amended for 1999, 3rd edn. Ashoka Law House, New Delhi

Badr MA, Talaab AS (2008) Response of tomatoes to nitrogen supply through drip irrigation system under salt stress conditions. Aust J Basic Appl Sci 2(1):149-156

Bassanino M, Grignani C, Sacco D, Allisiardi E (2007) Nitrogen balance at the crop and farm-gate scale in livestock farms in Italy. Agric Ecosyst Environ 122:282-294

Bationo A, Buerkert A (2001) Soil organic carbon management for sustainable land use in Sudano-Sahelian West Africa. Nutr Cycl Agroecosyst 61:131-142 
Berger M, Belem PC, Dakouo D, Hien V (1987) Le maintien de la fertilité des sols dans l'ouest du Burkina Faso et la nécessité de l'association agriculture-élevage. Coton Fibres Trop 42:201-210

Bernholt H, Kehlenbeck K, Gebauer HJ, Buerkert A (2009) Plant species diversity in urban and peri-urban gardens of Niamey, Niger. Agrofor Syst (in press). doi:10.1007/s10457009-9236-8

Binns T, Maconachie RA, Tanko AI (2003) Water, land and health in urban and peri urban food production. The case of Kano, Nigeria. Land Degrad Dev 14:431-444

Bray HR, Kurtz LT (1945) Determination of total organic and available forms of phosphorus in soils. Soil Sci 9:39-46

Bremer PJ, Fletcher GC, Osborne C (2004) Staphylococcus aureus. New Zealand Institute for Crop and Food Research Limited. Private Bag 4704. Christchurch, New Zealand, pp 1-6

Brouwer J, Powell JM (1998) Increasing nutrient use efficiency in West-African agriculture: the impact of micro-topography on nutrient leaching from cattle and sheep manure. Agric Ecosyst Environ 71:229-239

Bryld E (2003) Potentials, problems, and policy implications for urban agriculture in developing countries. Agric Hum Values 20:79-86

Centre Nationale d'Études et de Recommandations sur la Nutrition et l'Alimentation (CNERNA-CNRS) (1996) Produits de la IVe gamme. In: Jouve J (ed) La qualité microbiologique des aliments (maîtrise et critères). Polytechnica, Paris, France, pp 73-98

Chaney AL, Marbach EP (1962) Modified reagents for determination of urea and ammonia. Clin Chem 8:130-132

Cofie O, Drechsel P, Amoah P, Danso G, Gyiele L (2001) Improving rural-urban nutrient flows through urban and peri-urban agriculture. Paper prepared for the conference 'Rural-urban encounters: managing the environment of the peri-urban interface'. Development Planning Unit, University College London, 9-10 Nov 2001

Cofie OO, van Veenhuizen R, Drechsel P (2003) Contribution of urban and peri-urban agriculture to food security in Sub-Saharan Africa. Africa session of 3rd WWF, Kyoto

Dilkes NB, Jones DL, Farrar J (2004) Temporal dynamics of carbon partitioning and rhizodeposition in wheat. Plant Physiol 134:706-715

Dougill AJ, Twyman C, Thomas DSG, Sporton D (2002) Soil degradation assessment in mixed farming systems of southern Africa: use of nutrient balance studies for participatory degradation monitoring. Geogr J 168(3):195-210

Drechsel P, Abaidoo RC, Amoah P, Cofie OO (2000) Increasing use of poultry manure in and around Kumasi, Ghana: is farmers' race consumers' fate? Urban Agric Mag 2:25-27

Drechsel P, Giordano M, Gyiele L (2004) Valuing nutrients in soil and water: concepts and techniques with examples from IWMI studies in the developing world. Research Report 82. Colombo, Sri Lanka. International Water Management Institute

Drechsel P, Giordano M, Enters T (2005) Valuing soil fertility change: selected methods and case studies. In: Shiferaw B, Freeman HA, Swinton SM (eds) Natural resources management in agriculture: methods for assessing economic and environmental impacts. ICRISAT-CABI, Wallingford, pp 199-221
Drechsel P, Graefe S, Sonou M, Olufunke C (2006) Informal irrigation in urban West Africa: An overview. IWMI Research Report 102, Colombo, Sri Lanka, p 34

Drechsel P, Graefe S, Fink M (2007) Rural-urban food, nutrient and water flows in West Africa, IWMI Research Report 115. Colombo, Sri Lanka, p 35

Espiau P, Peyronel A (1976) L'acidité d'échange des sols, méthode de détermination de l'aluminium échangeable et des protons échangeables. Agric For Exp Stn Bull 3: $161-175$

FAO (2005) Bilan des éléments nutritifs du sol à différentes échelles. Application des méthodes intermédiaires aux réalités Africaines. Organisation des Nations Unies pour l'Alimentation et l'Agriculture. Rome, Italy. Bulletin FAO Engrais et Nutrition Végétale 15

Graefe S, Schlecht E, Buerkert A (2008) Opportunities and challenges of urban and peri-urban agriculture in Niamey. Outlook Agric 37:47-56

Guendel S (2002) Peri-urban and urban livestock keeping in East Africa. A coping strategy for the poor? Scoping study. Natural Resources International Limited, Aylesford, UK, p 31

Guo R, Li X, Christie P, Chen Q, Jiang R, Zhang F (2008) Influence of root zone nitrogen management and a summer catch crop on cucumber yield and soil mineral nitrogen dynamics in intensive production systems. Plant Soil 313: $55-70$

Gupta N, Khan SC, Santra SC (2008) An assessment of heavy metal contamination in vegetables grown in wastewaterirrigated areas of Titagarh, West Bengal, India. Bull Environ Contam Toxicol 80:115-118

He FF, Chen Q, Jiang RF, Chen XP, Zhang FS (2007) Yield and nitrogen balance of greenhouse tomato (Lycopersicum esculentum Mill.) with conventional and site-specific nitrogen management in Northern China. Nutr Cycl Agroecosyst 77:1-14

Heinrichs H (1989) Aufschlußverfahren in der Analytischen Geochemie (Teil 1). Labor-Praxis 12:1-6

Jorge MF (2006) Postharvest quality and microbial population of head lettuce as affected by moisture at harvest. Food Microbiol Saf 71(2):45-49

Ju XT, Kou CL, Christie P, Dou ZX, Zhang FS (2007) Changes in the soil environment from excessive application of fertilizers and manures to two contrasting intensive cropping systems on the North China Plain. Environ Pollut 145:497-506

Keraita B, Drechsel P (2002) use in informal irrigation in urban and peri-urban areas of Kumasi, Ghana. Urban Agric Mag 8:11-13

Keraita B, Konradsen F, Drechsel P, Abaidoo RC (2007) Reducing microbial contamination on wastewater-irrigated lettuce by cessation of irrigation before harvesting. Trop Med Int Health 12(2):8-14

Khai NM, Ha PQ, Öborn I (2007) Nutrient flows in small-scale peri-urban vegetable farming systems in Southeast Asiaa case study in Hanoi. Agric Ecosyst Environ 122:192202

Kyllingsbæk A, Hansen JF (2007) Development in nutrient balances in Danish agriculture 1980-2004. Nutr Cycl Agroecosyst 79:267-280

L'Hôte T, Mahé G, Somé B, Triboulet JP (2002) Analysis of a Sahelian annual rainfall index from 1896 to 2000; the drought continues. Hydrol Sci 47(4):563-572 
Lowry OH, Lopez JA (1946) The determination of inorganic phosphate in the presence of labile phosphate esters. Biol Chem 162:421-428

Lynch K, Binns T, Olofin E (2001) Urban agriculture under threat: the land security question in Kano, Nigeria. Cities 18(3):159-171

Maurice T (2003) Modélisation de la croissance urbaine et périurbaine autour des villes saheliennes: cas de Niamey. Internal Report, AGRHYMET, Niamey

Melloul AA, Hassani L, Rafouk L (2001) Salmonella contamination of vegetable irrigated with untreated wastewater. World J Microbiol Biotechnol 17:207-209

Nguni D, Mwila G (2007) Opportunities for increased production, utilization and income generation from African leafy vegetables in Zambia. Afr J Food Agric Nutr Dev 7(4): $1-20$

Nguyen C (2003) Rhizodeposition of organic C by plants: mechanisms and controls. Agronomie 23:375-396

Niang S, Diop A, Faruqui N, Redwood M, Gaye M (2002) Reuse of untreated wastewater in market gardens in Dakar, Senegal. Urban Agric Mag 8:35-36

Nielsen AH, Kristensen IS (2005) Nitrogen and phosphorus surpluses on Danish dairy and pig farms in relation to farm characteristics. Livest Prod Sci 96:97-107

Oenema O, Kros H, de Vries W (2003) Approaches and uncertainties in nutrient budgets: implication for nutrient management and environmental policies. Eur J Agron 20: 3-16

Pescod MB (1992) Wastewater treatment and use in agriculture. Irrigation and Drainage Paper 47. Food and Agriculture Organization of the United Nations, Rome

Pôrto ML, Alves JC, Souza AP, Araújo RC, Arruda JA (2008) Nitrate production and accumulation in lettuce as affected by mineral nitrogen supply and organic fertilization. Hortic Bras 26:227-230

Predotova M, Gebauer J, Diogo RVC, Schlecht E, Buerkert A (2010a) Gaseous nitrogen and carbon emissions from urban gardens in Niamey, Niger. Field Crops Res (accepted)

Predotova M, Bischoff W-A, Buerkert A (2010b) Leaching losses from urban vegetable production gardens in Niamey, Niger. J Plant Nutr Soil Sci (submitted)

PSEAU (2007) Laitue, chou et tomates. Projet de Sécurisation de l'Élevage et de l'Agriculture péri-urbains de Niamey. Fiche Techniques, Niamey, Niger

Quilfen JP, Milleville P (1983) Résidus de culture et fumure animale: un aspect des relations agriculture-élevage dans le nord de la Haute-Volta. Agron Trop 38:206-212

Rabinovitch J, Schmetzer H (1997) Urban agriculture: foods, jobs, and sustainable cities. Agric Rural Dev 4:44-45

RFA Methodology (1985) Nitrate/Nitrite A303-S170

Roy RN, Misra RV, Lesschen JP, Smaling EMA (2003) Assessment of soil nutrient balance approaches and methodologies. Rome, Italy. Food and Agriculture Organization of the United Nations. FAO Fertilizer and Plant Nutrition Bulletin 14
SAS (2003) SAS/STAT for Personal Computers. SAS Institute, Inc., Cary, NC

Schlecht E, Hiernaux P, Achard F, Turner MD (2004) Livestock related budgets within village territories in Western Niger. Nutr Cycl Agroecosyst 68:199-211

Schreurs M (2001) L'agriculture periurbaine: le cas du maraîchage à Lomé. IFDC-Afrique. Document de Travail, Lomé, $12 \mathrm{pp}$

Smith SR, Hadley P (1992) Nitrogen fertilizer value of activated sewage derived protein: effect of environment and nitrification inhibitor on $\mathrm{NO}_{3}{ }^{-}$release, soil microbial activity and yield of summer cabbage. Fert Res 33:47-57

Sonou M (2001) Peri-urban irrigated agriculture and health risks in Ghana. Urban Agric Mag 3:33-34

Stamatiadis S, Werner M, Buchanan M (1999) Field assessment of soil quality as affected by compost and fertilizer application in a broccoli field, San Benito County, California. Appl Soil Ecol 12:213-225

Stine SW, Song IH, Choi CY, Gerba CP (2005) Application of microbial risk assessment to the development of standards for enteric pathogens in water used to irrigate fresh produce. J Food Prot 68:913-918

Stoorvogel JJ, Smaling EMA (1990) Assessment of soil nutrient depletion in Sub-Saharan Africa: 1983-2000. Report 28, DLO Winand Staring Centre for Integrated Land, Soil and Water Research (SC-DLO), Wageningen, Netherlands

The International Commission on Microbiological Specifications for Food (ICMSF) (1974) Microorganisms in foods. Sampling for microbiological analysis: principles and specific applications. ICMSF, University of Toronto Press, Toronto

Thornton A (2008) Beyond the metropolis: small town case studies of urban and peri-urban agriculture in South Africa. Urban Forum 19:243-262

Van den Bosch H, Gitari JN, Ogaro VN, Maobe S, Vlaming J (1998) Monitoring nutrient flows and economic performance in African farming systems (NUTMON). III. Monitoring nutrient flows and balances in three districts in Kenya. Agric Ecosyst Environ 71:63-80

van Veenhuizen R, Danso G (2007) Profitability and sustainability of urban and peri-urban agriculture. Rome, FAO

Walkley A, Black CA (1934) An examination of the Degtjareff method for determining soil organic matter, and a proposed modification of the chromic acid titration method. Soil Sci 37:29-39

Yamoah CF, Bationo A, Shapiro B, Koala S (2002) Trend and stability analyses of millet yields treated with fertilizer and crop residues in the Sahel. Field Crops Res 75:53-62

Yusuf AA, Arowolo TA, Bamgbose O (2003) Cadmium, copper and nickel levels in vegetables from industrial and residential areas of Lagos City, Nigeria. Food Chem Toxicol 41:375-378 